Trinity University

Digital Commons @ Trinity

1999

\title{
A Review of the Pikes Peak Batholith, Front Range, Central Colorado: A "Type Example" of A-Type Granitic Magmatism
}

Diane R. Smith

Trinity University, dsmith@trinity.edu

J. Noblett

R. A. Wobus

D. Unruh

K. R. Chamberlain

Follow this and additional works at: https://digitalcommons.trinity.edu/geo_faculty

Part of the Earth Sciences Commons

\section{Repository Citation}

Smith, D. R., Wobus, R. A., Noblett, J. B., Unruh, D., and Chamberlain, K. (1999). A review of the Pikes Peak Batholith, front range, central Colorado: A 'type example' of A-type granitic magmatism. Rocky Mountain Geology, 34(2), 289-312. http://doi.org/10.2113/34.2.289

This Article is brought to you for free and open access by the Geosciences Department at Digital Commons @ Trinity. It has been accepted for inclusion in Geosciences Faculty Research by an authorized administrator of Digital Commons@ Trinity. For more information, please contact jcostanz@trinity.edu. 


\title{
A review of the Pikes Peak batholith, Front Range, central Colorado: A "type example" of A-type granitic magmatism
}

\author{
Diane R. Smithi*, Jeff Noblett ${ }^{2}$, Reinhard A. Wobus ${ }^{3}$, Dan Unruh", and \\ Kevin R. Chamberlain ${ }^{5}$ \\ ${ }^{1}$ Department of Geosciences, Trinity University, 715 Stadium Drive, San Antonio, TX 78212-7200, U.S.A. \\ dsmith@trinity.edu \\ ${ }^{2}$ Department of Geology, Colorado College, Colorado Springs, CO 80903, U.S.A. \\ ${ }^{3}$ Department of Geology, Williams College, 947 Main Street, Williamstown, MA 01267, U.S.A. \\ ${ }^{4}$ U.S. Geological Survey, MS963, Box 25046, Federal Center, Denver, CO 80225, U.S.A. \\ ${ }^{5}$ Department of Geology and Geophysics, P.O. Box 3006, University of Wyoming, Laramie, WY 82071-3006, \\ U.S.A. \\ *Author to whom correspondence should be addressed.
}

\section{ABSTRACT}

The 1.08-Ga Pikes Peak composite batholith of central Colorado is a type example of an Atype granitic system. From the 1970s through the 1990s, details of the field relations, mineralogy, major and trace element compositions, and isotopic geochemistry of Pikes Peak rocks were documented, and they reveal the existence of two chemical groups, a potassic and a sodic series. The potassic series ( $\left.\sim 64-78 \mathrm{wt} \% \mathrm{SiO}_{2}\right)$ includes the Pikes Peak Granite, which is mostly coarse-grained biotite \pm hornblende syenogranite and minor monzogranite that dominates the batholith. The potassic series also includes fine- to medium-grained biotite granite found in numerous, small, late-stage plutons throughout the batholith. The sodic series is found in seven plutons comprised of a wide range of rock types ( $\left.\sim 44-78 \mathrm{wt} \% \mathrm{SiO}_{2}\right)$, including gabbro, diabase, syenite/quartz syenite, and fayalite and sodic amphibole granite.

Differences in petrologic and geochemical characteristics between the sodic and potassic series indicate different petrogenetic histories. Major and trace element and strontium and oxygen isotopic data were used by some workers to hypothesize that mantle-derived alkali basalt underwent crystal fractionation and reaction with lower crustal rocks to generate syenitic magmas of the sodic series, which subsequently underwent further fractionation to produce sodic granites. Recent studies involving estimates of oxygen fugacities, along with additional trace element and neodymium isotopic data, also support a basalt fractionation model for the sodic series, but suggest only minor crustal involvement. Gabbros and diabase dikes associated with the sodic series appear to have been derived from mantle sources that previously had been affected by a subduction event, based on neodymium isotopic and trace element data.

Some workers propose that the potassic series also formed by fractionation of syenitic and/ or basaltic magmas coupled with reaction with intermediate rather than lower crust. Other workers propose a model in which genesis of the potassic series was dominated by partial melting involving tonalitic sources, with fractionation and perhaps magma mixing playing subordinate roles in generating compositional diversity among the potassic granitoids. The Pikes Peak batholith thus formed by emplacement of at least two petrogenetically different granite types, which were emplaced close together in space and time and which exhibit geochemical characteristics typical of A-type granites.

KEY WORDS: Colorado, geochemistry, petrology, granite, Proterozoic. 


\section{INTRODUCTION}

The "alphabet" division of granitoids into I-, S-, A-, and M-types (Chappell and White, 1974; Loiselle and Wones, 1979; Pitcher, 1983) has been prevalent in the petrologic literature for more than two decades. The abstract in which Loiselle and Wones (1979) proposed the A-type category has been cited over 135 times, according to the Science Citation Index. They included several granitoid suites as examples of A-type granites, including the White Mountain magma series of New Hampshire, Nigerian Younger Granites, and Gardar Province, Greenland. However, it was primarily the characteristics of the Pikes Peak batholith that motivated Loiselle and Wones to create this nomenclature (F. Barker, 1999, personal communication). A-type granitoid suites are characterized by high $\mathrm{FeO} /(\mathrm{FeO}$ $+\mathrm{MgO}$ ) and $\mathrm{K}_{2} \mathrm{O} / \mathrm{Na}_{2} \mathrm{O}$, and high $\mathrm{K}_{2} \mathrm{O}$ contents, and they usually contain anhydrous iron- and alkali-rich phases such as fayalite and hedenbergite, as well as annite and sodium-rich amphiboles, reflecting crystallization under low water and oxygen fugacities (Barker et al., 1975, 1976; Loiselle and Wones, 1979; Anderson, 1983; Frost and Frost, 1997). Abundances of incompatible trace elements in A-type granites typically are high for rare earth elements (REE; except $\mathrm{Eu}$ ), Zr, $\mathrm{Nb}, \mathrm{Y}, \mathrm{Hf}$, Ta, and $\mathrm{Ga}$, but low for $\mathrm{Sr}$, $\mathrm{Eu}, \mathrm{Sc}, \mathrm{Ni}$, Cr, and Co (Barker et al., 1976; Whalen et al., 1987).

The A-type designation has been broadly applied to granites that are anorogenic, alkaline, and relatively anhydrous in nature, but which often exhibit subtle to significant differences in mineralogy, petrochemistry, and/or tectonic setting. Thus, of the numerous petrogenetic models that have been presented for A-type granites, no single model can be universally applied. Petrogenetic models for Atype granites generally fall into two categories: those invoking extreme fractionation of mantle-derived magmas, with or without crustal assimilation (e.g., Barker et al., 1975; Turner et al., 1992), and those involving partial melting of crustal sources such as tonalite/granodiorite (e.g., Anderson and Morrison, 1992), residual lower crust (e.g., Collins et al., 1982), or underplated tholeiitic basalts (e.g., Frost and Frost, 1997).

The Pikes Peak batholith and its late-stage plutons are comprised of a tremendous volume of granitic rocks. Variations in mineralogy, rock associations, major and trace element abundances, and isotopic characteristics within the batholith imply different origins (Barker et al., 1975), probably including both crustal anatexis and fraction- ation of mantle-derived magmas (Barker et al., 1976; Smith et al., 1999). In addition, magma mixing/ mingling and fractionation of crustal melts are thought to have played roles in generating some of the compositional diversity among Pikes Peak rocks (Barker et al., 1976; Chastain and Noblett, 1994; Smith et al., 1999). Thus, we still consider the Pikes Peak batholith to serve as a useful "type" example of A-type granitic magmatism because it may illustrate the diversity in source and process that can generate such magmas.

In this paper, we summarize the geologic setting of the Pikes Peak batholith and review the studies conducted on the batholith to date, focusing on those that have relevance to petrogenetic models for the magmas emplaced in the batholith. We review previously obtained isotopic dates for the batholith and present a newly acquired date for a sample from the West Creek intrusion. We then highlight the petrologic and geochemical characteristics of Pikes Peak rocks, and discuss petrogenetic models that explain those characteristics. Finally, we compare the petrology, geochemistry, and tectonic setting of the Pikes Peak batholith with two other $\sim 1.1-$ Ga granitic systems in North America, the Red Bluff suite (Franklin Mountains, west Texas) and granites of the Llano uplift (central Texas).

\section{GEOLOGIC SETTING}

The Front Range and Wet Mountains provide the largest continuous exposure of Lower to Middle Proterozoic metamorphic and plutonic rocks in Colorado. They are part of the Yavapai-Mazatzal province (Hoffman, 1988; Fig. 1), a $>1000 \mathrm{~km}$-wide belt that was added to the southern margin of the Archaean Wyoming craton between 1790 and 1660 Ma (Reed et al., 1987). The protoliths of the metamorphic rocks have been interpreted as relics of arc magmatism and related sedimentary basins developed along the southern edge of the craton (Reed et al., 1987). These materials were consolidated at $\sim 1.8-1.7 \mathrm{Ga}$ during deformation, metamorphism (mostly under amphibolite facies conditions), and plutonism referred to as the Yavapai orogeny (Reed et al., 1987; Karlstrom and Bowring, 1987; additional references in Hoffman, 1988). The metamorphic rocks were intruded by granitoid magmas during three major Precambrian magmatic events: the Boulder Creek at $\sim 1.7 \mathrm{Ga}$, the Silver Plume at $\sim 1.4 \mathrm{Ga}$, and the Pikes Peak at $\sim 1.1$ $\mathrm{Ga}$ (Wobus and Hutchinson, 1988). The Boulder Creek rocks are well-foliated and locally folded, 
bearing the imprint of the regional metamorphic event that deformed their wall rocks; in contrast, the Silver Plume and Pikes Peak rocks lack foliation (Tweto, 1980b; Wobus and Hutchinson, 1988). Boulder Creek rocks are composed of calc-alkaline tonalite and granodiorite with lesser granite (e.g., Gable, 1980), whereas the Silver Plume rocks are peraluminous, two-mica granitoids (e.g., Anderson, 1983).

The exposed area of the Pikes Peak batholith is about $3100 \mathrm{~km}^{2}$ (Tweto, 1980a; Fig. 2). On its north, south, and west margins, it intrudes older granites and metamorphic rocks and is faulted on the eastern margin by the Ute Pass and Rampart fault zones. On the basis of a pronounced negative magnetic expression (Zietz and Kirby, 1972) and a continuous magnetic low, Tweto (1980b) inferred that perhaps as much as half of the batholith is unexposed and extends eastward in the subsurface.

The batholith is composite in nature (see, e.g., Hutchinson, 1976; Scott et al., 1978; Bryant et al., 1981; and Wobus and Hutchinson, 1988), composed of three large intrusive centers $\sim 20-25 \mathrm{~km}$ in diameter (Hutchinson, 1960a, 1960b, and 1976), as well as numerous late-stage stocks and plutons ranging from $<2-\sim 8 \mathrm{~km}$ in diameter (Wobus, 1976a). Granite is dominant, but the spectrum of rock types found in the batholith is large ( $\sim 45-78 \mathrm{wt} \% \mathrm{SiO}_{2}$ ) and can be divided into two chemical series. Barker et a1. (1975) noted the existence of sodic and potassic "trends" for rocks of the Pikes Peak batholith. Wobus (1976a) used this terminology and found that the potassic plutons have $\mathrm{Na}_{2} \mathrm{O} / \mathrm{K}_{2} \mathrm{O}$ ratios of $<1.0$, whereas the sodic plutons generally have higher ratios. Here we use the terms potassic series and sodic series to distinguish among the rocks of the Pikes Peak batholith. The potassic series includes generally coarse grained, biotite \pm hornblende pink syenogranites and minor gray monzogranites, herein referred to as the Pikes Peak Granite (PPG). The PPG was emplaced in at least three major intrusive centers, including the Lost Park, Buffalo Park, and Pikes Peak centers (cf. Fig. 2; Hutchinson, 1976). The potassic series also includes smaller, late-

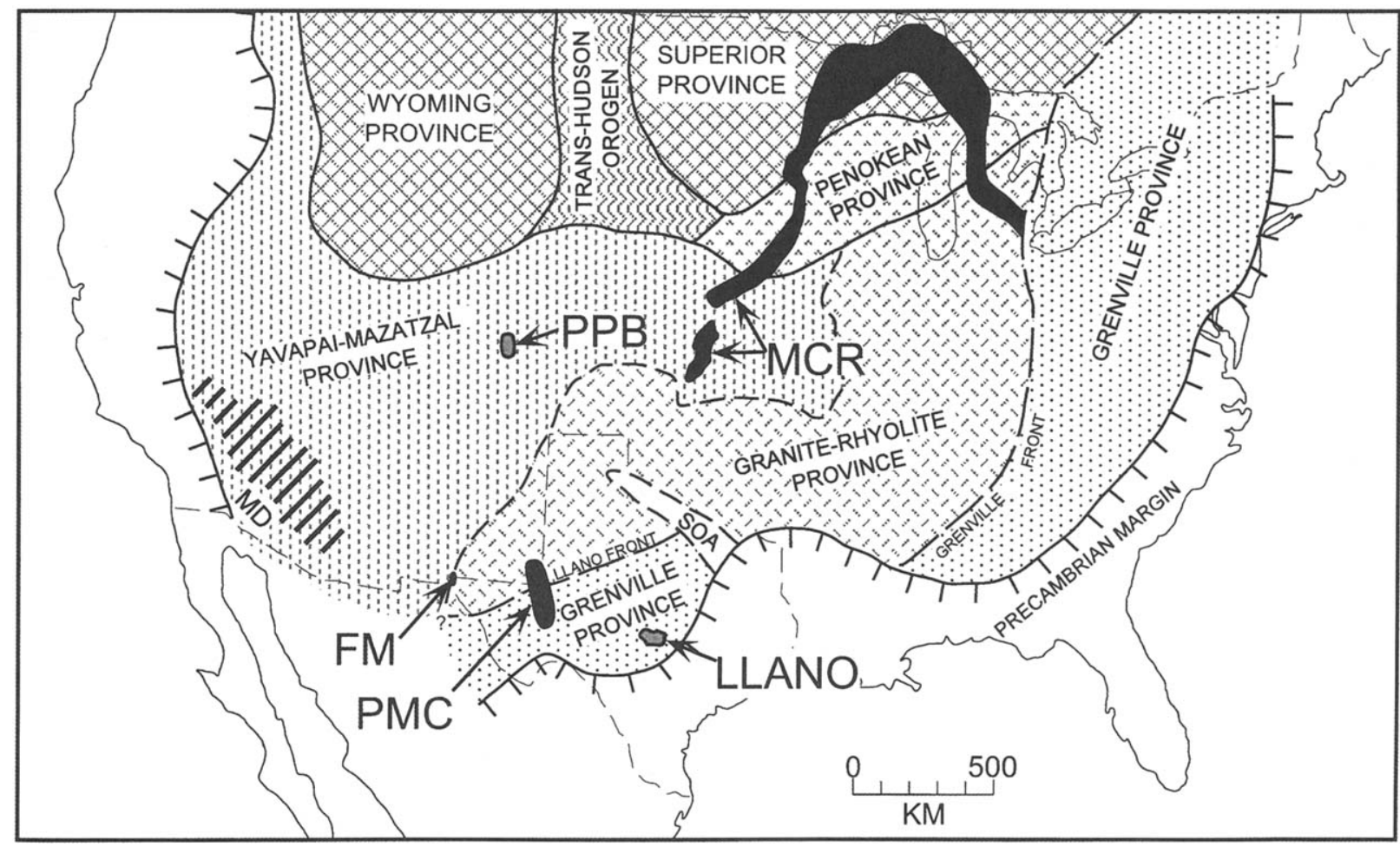

Figure 1. Simplified map of Precambrian provinces in central North America showing the Archean Wyoming and Superior provinces, 1.8-2.5-Ga Penokean province and Trans-Hudson orogen, and the younger Yavapai-Mazatzal (1.55-1.80 Ga), Granite-Rhyolite (1.34-1.50 Ga), and Grenville (1.1-1.35 Ga) provinces to the south (after Bickford, 1988). Circa 1.1-Ga granitic systems include the Pikes Peak batholith (PPB) in central Colorado, the Red Bluff suite in the Franklin Mountains (FM) of west Texas, and granites of the Llano uplift of central Texas. Also shown are the MidContinent Rift (MCR), the Pecos mafic intrusive complex (PMC), and dikes and sills of the Mojave Desert region (MD). SOA is the Cambrian southern Oklahoma aulacogen. 
$105^{\circ}$

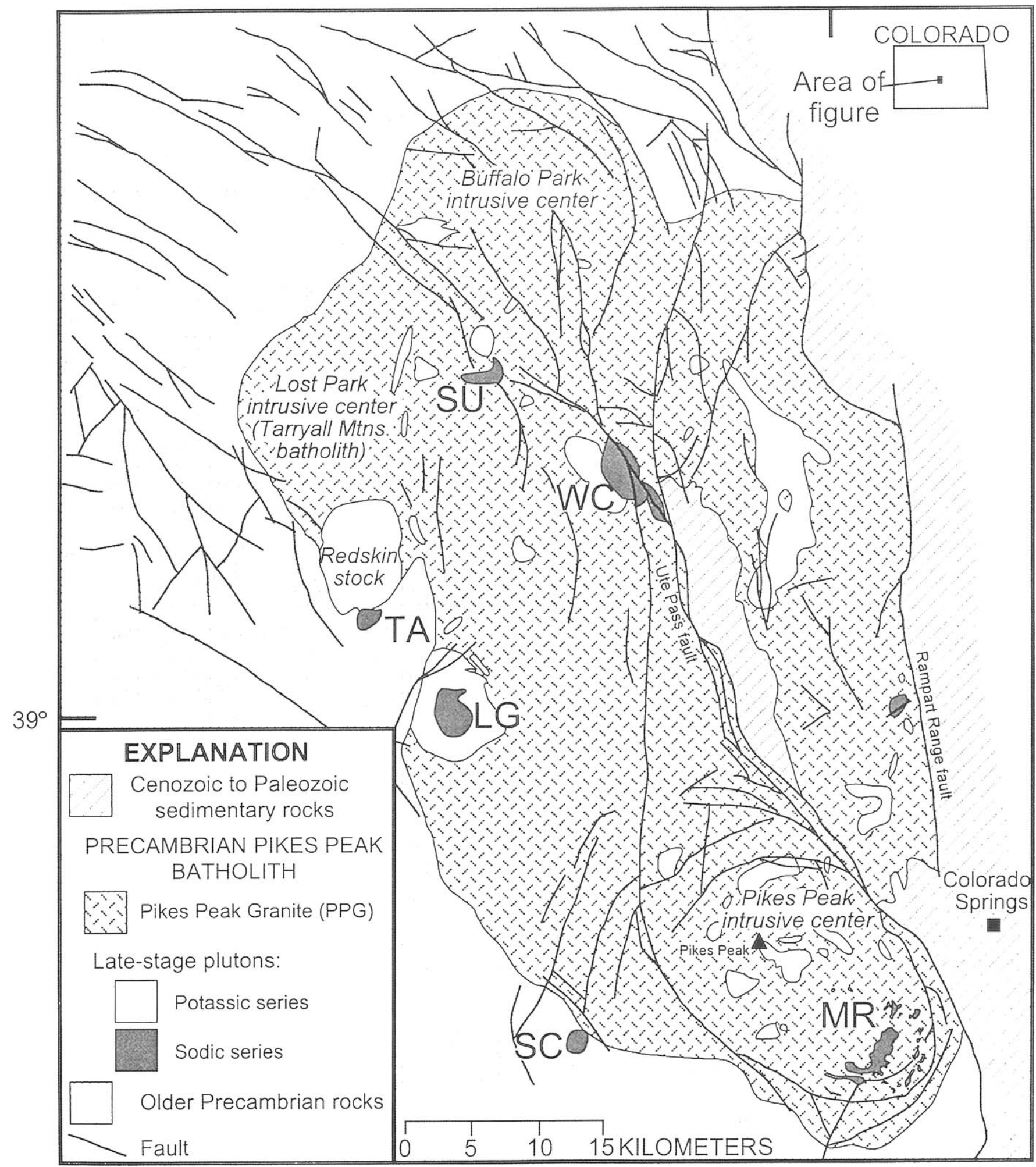

Figure 2. Geologic map of the Pikes Peak batholith (after Bryant et al., 1981, and Scott et al., 1978). The main phase of the batholith is generally composed of coarse-grained pink granite (associated with minor gray monzogranite) referred to here as Pikes Peak Granite (PPG). The PPG comprises the Buffalo Park, Lost Park, and Pikes Peak intrusive centers. Late-stage plutons include fine-grained granites of the potassic series in many unnamed intrusions distributed throughout the batholith (e.g., at the summit of Pikes Peak). Sodic series plutons include Sugarloaf (SU), Tarryall (TA), West Creek (WC), Lake George (LG), Spring Creek (SC; sometimes called the Cripple Creek stock, e.g., Sage, 1966), and the Mount Rosa intrusive complex (MR). 
stage plutons of fine- to medium-grained, commonly porphyritic, potassic granite, and minor quartz monzonite such as the Windy Point Granite of Pikes Peak, which are distributed throughout the batholith (Wobus, 1976a; cf. Fig. 2). Rocks of the sodic series comprise less than 2 percent of the volume of the batholith and are found in seven small, late-stage intrusive centers in and immediately adjacent to the batholith (Wobus, 1976a; Fig. 2). They include a wide range of compositions, ranging from gabbro, to syenite and quartz syenite, to fayaliteand sodic amphibole-bearing granite (Barker et al., 1975, 1976; Wobus, 1976a; Wobus and Anderson, 1978).

\section{PREVIOUS STUDIES}

\section{Geology and Petrology}

In an important contribution published in 1975, Barker and his colleagues provided a concise description of work conducted on the Pikes Peak batholith prior to that time. They cited turn-of-thecentury petrographic and field studies of the batholith by Mathews $(1895,1900)$, Cross (1894), and Finlay (1916). Several workers added significant studies on the batholith in the 1960s and 1970s. Hutchinson (1960b, 1976) mapped structures and rock units within the batholith in detail. His studies documented the Buffalo Park, Lost Park (renamed the Tarryall Mountains batholith by Hawley and Wobus, 1977), and Pikes Peak intrusive centers (cf. Fig. 2). Each of these centers is $\sim 20-25 \mathrm{~km}$ in diameter, and they occur at different but overlapping elevations. Hutchinson mapped flow structures and primary fracture systems that defined inwarddipping, funnel shaped patterns within each center, indicating that magma was fed into the centers at an angle of $65^{\circ}-80^{\circ}$ along $S 40^{\circ}-50^{\circ} \mathrm{E}$ direction. Other studies were conducted by Hawley and his colleagues (Hawley et al., 1966; Hawley, 1969; Hawley and Wobus, 1977), who worked in the Tarryall Mountains and Redskin stock, and by Gross and Heinrich $(1965,1966)$, who focused on the Mount Rosa intrusive center. Sage (1966) and Stewart (1964) completed master's theses on the Cripple Creek and Lake George intrusive centers, respectively.

In the mid-1970s, the batholith was remapped by the U.S. Geological Survey at a scale of 1:250,000 (Scott et al., 1978; Bryant et al., 1981). These studies provided details of the geology and petrology of the sodic and late potassic plutons. Six of the seven sodic plutons were noted to be aligned along two linears trending $\mathrm{N} 50^{\circ} \mathrm{W}$ (Wobus, 1976a), and four of the plutons were found to have ring dike-like patterns (Wobus, 1976a, 1976b; Wobus and Anderson, 1978). Potassic granites of the late-stage intrusions were recognized to be similar to the PPG that dominates the batholith and were interpreted as rapidly cooled textural variants (Wobus, 1976a, 1976b).

Field trip road logs for the Pikes Peak area have been published by several workers, including Hutchinson (1960a), Hutchinson and Hedge (1967), Epis et al. (1973), Bryant et al. (1976), and Wobus and Hutchinson (1988). These documents include maps and reviews of the geology of the batholith. The log of Bryant et al. (1976) includes discussions of geochemical studies and petrogenetic interpretations.

\section{Mineralogy and Intensive Parameters}

Much research has focused on the mineralogy of the Pikes Peak batholith, especially that of its many pegmatites. Even the earliest studies (e.g., Cross and Hillebrand, 1882) noted the interesting minerals found in the region, which is a very popular 'rockhounding' locality (Voynick, 1994). The batholith has produced some of the finest known examples of amazonite and smoky quartz, which occur with nearly 60 other mineral species in pegmatites (Muntyan and Muntyan, 1985). Numerous abstracts and papers on Pikes Peak pegmatites and associated minerals (including field guides and road logs) were published in the Colorado Pegmatite Symposium volume (Modreski et al., 1986). The best-studied pegmatites occur in the South Platte district within the Buffalo Park intrusive center (cf. Fig. 2). Hanley et al. (1950), Heinrich (1958), Peterson (1964), and Haynes (1965) conducted early studies of the South Platte district. More recently, Simmons and his colleagues have produced numerous contributions on the detailed mineralogy and geochemistry of this district (Simmons, 1977; Simmons and Heinrich, 1975; 1980; Brewster, 1986; Lee, 1986; Wayne, 1986; Simmons et al., 1986, 1987a, 1987b; Simmons and Hanson, 1991). Although many of the mineralogical studies focus on the details of rare minerals occurring in the batholith (e.g., Pauly, 1954; Adams and Young, 1961; Foord et al., 1984; contributions in Modreski et al., 1986), the work by Simmons et al. (1987b) has significance for models of magma evolution (see discussion below).

The extremely iron-rich nature of the ferromagnesian silicates in Pikes Peak rocks has been documented with wet chemical and microprobe analyses 
(Barker et al., 1975, Giambalvo, 1993). Fayalite is extremely poor in magnesium, with less than 1 mole \% forsterite. Molar $\mathrm{Fe} /$ $(\mathrm{Fe}+\mathrm{Mg})$ in biotite and hedenbergite is $>0.92$ and $~ 0.97$, respectively (Barker et al., 1975). A variety of amphiboles is present in Pikes Peak rocks, including edenitic hornblende, edenite, and actinolitic hornblende in syenites and fayalite granites from West Creek, Lake George, and Mount Rosa; richterite and winchite in syenites from Sugarloaf; and arfvedsonite (and minor riebeckite) in granites from Mount Rosa (Giambalvo, 1993). All of the amphiboles are very iron rich, with molar $\mathrm{Fe} /$ $(\mathrm{Fe}+\mathrm{Mg})$ generally greater than 0.95 (Giambalvo, 1993).

As is generally the case for Atype granites, the anhydrous and/ or iron-rich nature of ferromagnesian silicates in the Pikes Peak granitoids reflects conditions of relatively low water and oxygen fugacities (Barker et al., 1975; Loiselle and Wones, 1979). The coexistence of hedenbergitic pyroxene + ilmenite with fayalite in some of the sodic granites implies crystallization under relatively low oxygen fugacities (Wones, 1989). Using quartz + ulvöspinel + ilmenite + fayalite equilibrium ("QUIlF"), Frost et al. (1988) calculated oxygen fugacities at or below (by 1.5 log units) the quartz-fayalite-magnetite buffer for sodic syenites and granites. Frost et al. (1988) estimated temperatures in the range of $970^{\circ}-650^{\circ} \mathrm{C}$ for sodic granitic magmas, although they noted that the low end of the range may reflect subsolidus re-equilibration. Saltoun (1993) and Beane (1993) estimated temperatures based on zircon and apatite saturation (Watson and Harrison, 1983; Harrison and Watson, 1984). Their temperatures ranged from $966^{\circ}-865^{\circ} \mathrm{C}$ and from $961^{\circ}-$ $724^{\circ} \mathrm{C}$ for sodic granites and syenites, respectively. Thus, it appears that Pikes Peak sodic magmas had melt temperatures that probably exceeded $950^{\circ} \mathrm{C}$. Shallow emplacement of these magmas ( $<5 \mathrm{~km}$; Barker et al., 1975 ) is consistent with estimates of high temperature and low water contents.

Based on phase chemistry, few estimates of intensive parameters have been made for Pikes Peak potassic magmas. However, Barker et al. (1975) showed that the potassic granites plot toward the orthoclase apex in the normative quartz-albite-orthoclase ternary, rather than along minimum melt compositions of water-saturated granites. They interpreted this as indicating crystallization under conditions of low water activity $\left(\mathrm{P}_{\mathrm{H} 2 \mathrm{O}}<\mathrm{P}_{\text {total }}\right)$ but at relatively higher $f_{\mathrm{H} 2 \mathrm{O}}$ than for the sodic magmas. The mag. mas probably did not reach water saturation until late in the crystallization history, but the presence of accessory fluorite (Barker et al., 1975) suggests that fluorine was an important mag. matic volatile.

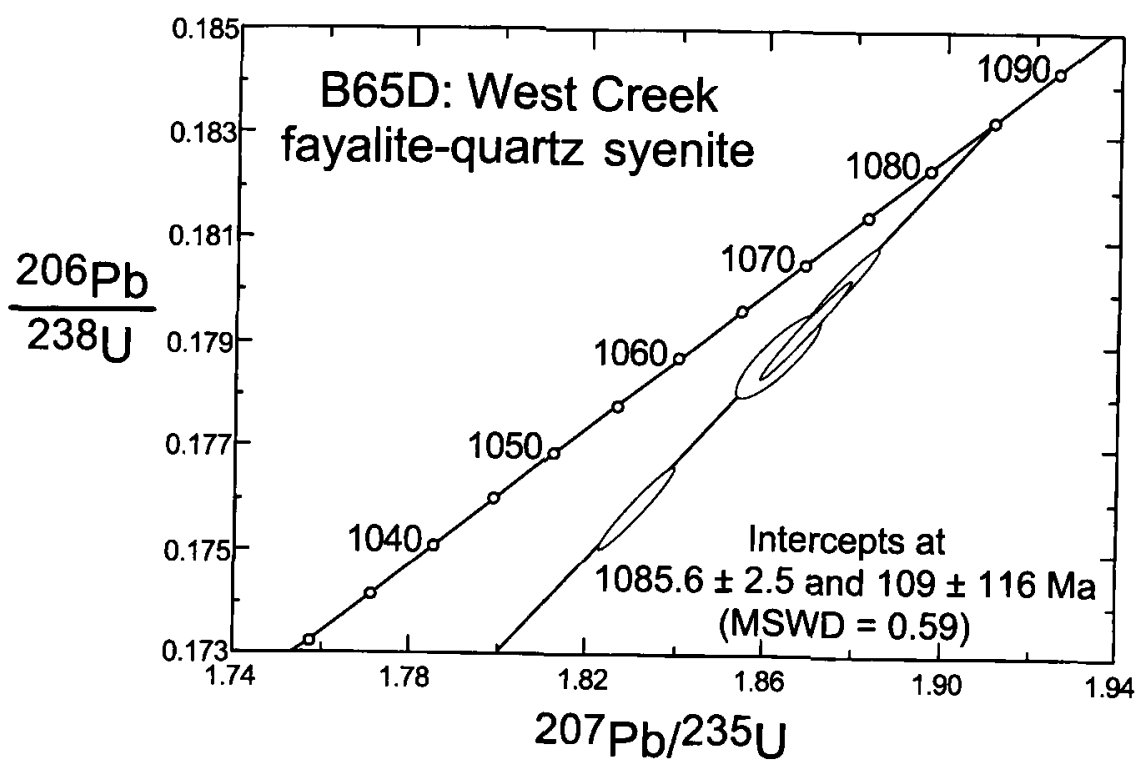

Figure 3. Concordia plot of U-Pb zircon data from West Creek fayalite-quartz syenite (B65D).

\section{Geochemistry}

In the context of new mapping conducted in the 1970s, Barker et al. $(1975,1976)$, Wobus (1976a), and Wobus and Anderson (1978) analyzed a wide spectrum of rock types, from gabbro to alkali granite, for their major element compositions. These studies discovered the different chemical trends for the potassic and sodic series, which were interpreted as the result of separate differentiation trends (see following discussion on petrogenetic models). In another contribution, Barker et al. (1976) presented strontium, oxygen, and deuterium-hydrogen isotopic analyses and REE abundances for Pikes Peak rocks, which they interpreted as generally but not wholly supportive of the petrogenetic model set forth in Barker et al. (1975).

DePaolo (1981) published a single neodymium isotopic analysis of Pikes Peak granite. Its composition lies along the crustal evolution line for 1.8-Ga Colorado crust, and DePaolo interpreted the granite as the differentiation 
product of mantle-derived basaltic magma that evolved by crystallization and crustal assimilation processes.

Ludington (1981) and Simmons et al. (1987b) provided major and trace element analyses of some of the potassic intrusive rocks. Ludington studied the Redskin granite stock, the largest of the late potassic plutons, and PPG from the Tarryall Mountains (Lost Park intrusive center). Simmons et al. (1987b) analyzed quartz monzonite (monzogranite), granites, and pegmatite wall rocks of the South Platte pegmatite district in the Buffalo Park intrusive center. Both of these studies led the authors to conclude that processes besides fractional crystallization and/or partial melting affected some Pikes Peak granitic magmas.

In 1992, the Keck Geology Consortium sponsored a faculty-student research project that focused on the late-stage alkalic intrusive centers of the batholith. New microprobe analyses of amphiboles, whole-rock major and trace element analyses, and neodymium isotopic analyses of Pikes Peak rocks resulted from these studies. Preliminary results were published in the Keck Symposium abstracts volume (Woodard, 1993), and in abstracts published by Beane and Wobus (1993), Douglass and Smith
(1993), Sturm et al. (1993), Goldman et al. (1994), and Stewart (1994). A recent article by Smith et al. (1999) presents the major and trace element and $\mathrm{Nd}$ isotopic analyses of Pikes Peak rocks generated from these studies. Smith et al. support earlier proposals that fractionation of mantle-derived mafic magmas was the major petrogenetic process involved in the origin of the sodic series, whereas the origin of the potassic series was dominated by crustal anatexis.

\section{GEOCHRONOLOGY}

Early age determinations were presented by many workers in the 1950 s to early 1970s (e.g., Aldrich et al., 1957; Tilton et al., 1957; Hutchinson, 1959a, 1959b; Giffin and Kulp, 1960; Hawley et al., 1966; Hedge, 1970). Gross and Heinrich (1965), Peterman and Hedge (1968), and Hutchinson (1976) provided compilations of the available ages, which ranged from 980-1080 Ma, or 930-1060 Ma when current values for the decay constants are used.

More recently, Marshall and DePaolo (1982) determined an age of $1041 \pm 32$ Ma for Pikes Peak granite using the $\mathrm{K} / \mathrm{Ca}$ geochronometer. Unruh (unpublished data) has obtained U-Pb zircon ages of

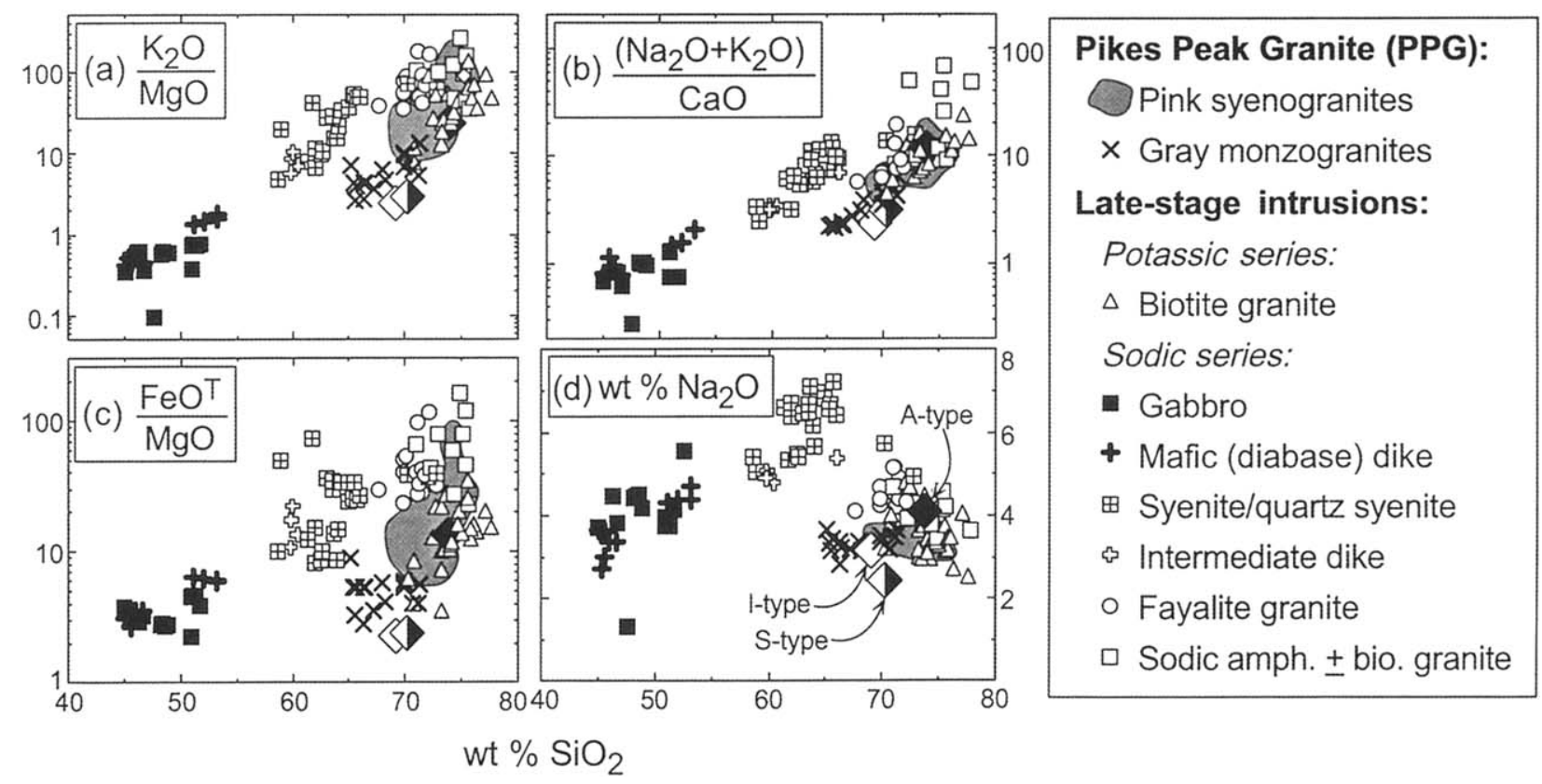

Figure 4. A, $\log \mathrm{K}_{2} \mathrm{O} / \mathrm{MgO} ; \boldsymbol{B}, \log \left(\mathrm{Na}_{2} \mathrm{O}+\mathrm{K}_{2} \mathrm{O}\right) / \mathrm{CaO} ; \boldsymbol{C}, \log \mathrm{FeO}^{\mathrm{T}} / \mathrm{MgO}$ and $\mathrm{D}, \mathrm{Na}_{2} \mathrm{O}$ (wt \%) versus weight \% SiO ${ }_{2}$ for Pikes Peak rocks. $\mathrm{FeO}^{\mathrm{T}}=\left(0.9 \times \mathrm{Fe}_{2} \mathrm{O}_{3}\right)+\mathrm{FeO}$, and major element data were normalized to $100 \%$ on an anhydrous basis prior to plotting. Data sources include Barker et al. (1975), Wobus (1976a), Wobus and Anderson (1978), Simmons et al. (1987b), and Smith et al. (1999). For clarity, a shaded field includes the mostly pink, coarse-grained syenogranites that dominate the PPG. See legend for symbols. Data points for average S-, I-, and A-type granites are from Whalen et al. (1987). 


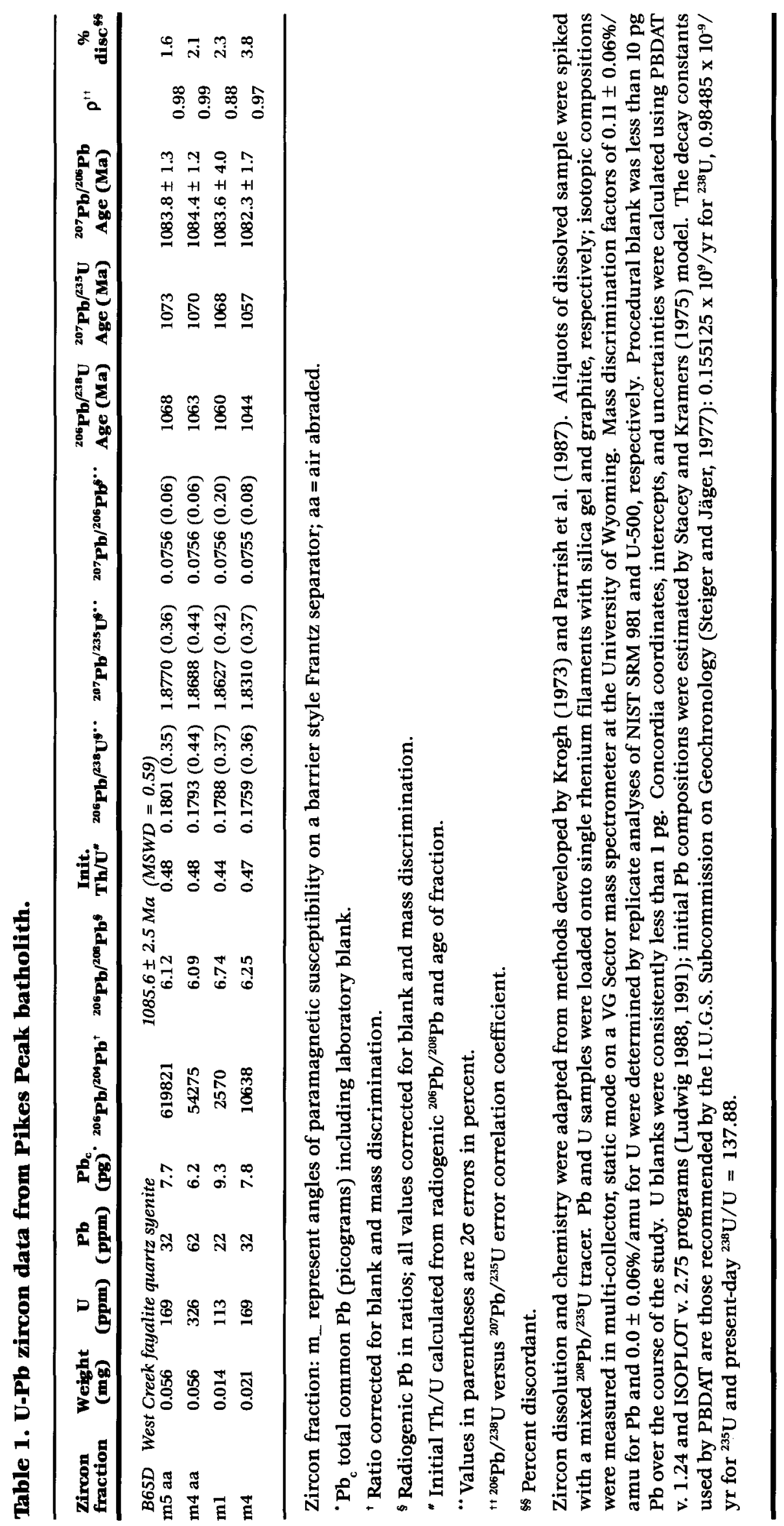


1085-1090 Ma for PPG, 1072 Ma for the Tarryall Mountains batholith (Lost Park intrusive center), 1070-1090 Ma for late potassic series plutons, and $\sim 1077-1087 \mathrm{Ma}$ for sodic plutons. There is no obvious relationship between spatial occurrence and age, as both the youngest ages (Redskin stock, Tarryall Mountains batholith) and oldest ages (potassic granites in and around the Lake George complex) thus far obtained by Unruh have been found along the western margin of the batholith.

Schärer and Allègre (1982) obtained an age of $1093 \pm 20$ Ma for a syenite at West Creek in the eastern part of the batholith (sample B65D, fayalitequartz syenite of Barker et al., 1975). We present here a date of 1085.6 $\pm 2.5 \mathrm{Ma}$ for this sample (B65D) recently analyzed at the University of Wyoming. Table 1 and Figure 3 present the U-Pb data, analytical methods, and concordia plot for this new age, which exhibits smaller error than the previously determined date.

\section{GEOCHEMICAL CHARACTERISTICS OF THE PIKES PEAK BATHOLITH}

\section{Introduction}

In this section, we highlight the major characteristics of whole-rock chemistry of samples from the Pikes Peak batholith, including major and trace element and isotopic characteristics. Data sources include Barker et al. (1975, 1976), Wobus (1976a), Wobus and Anderson (1978), Simmons et al. (1987b), and Smith et al. (1999) unless otherwise noted. The data are presented in selected geochemical plots in Figures 4 through 10.

\section{Major Elements}

Most Pikes Peak mafic rocks (gabbro and diabase) exhibit relatively low Mg-numbers (molar $\mathrm{Mg}$ / $(\mathrm{Mg}+\mathrm{Fe}) \times 100)$, from 24 to 43 , indicating a fairly evolved nature for these mafic rocks (however, one sample with Mg-number of 64 appears to be a cumulate rock). There are fairly large variations in alkalis and minor elements among the mafic rocks, which exhibit no obvious correlations with $\mathrm{SiO}_{2}$ or MgO (e.g., Fig. 4).

All granitoids of the Pikes Peak batholith exhibit the characteristics that distinguish A-type from S- and I-type granitoids (cf. Whalen et al., 1987). Atype granites have higher alkalis and iron, but lower calcium and magnesium, contents than S- and Itypes. $\mathrm{K}_{2} \mathrm{O} / \mathrm{MgO},\left(\mathrm{Na}_{2} \mathrm{O}+\mathrm{K}_{2} \mathrm{O}\right) / \mathrm{CaO}$, and $\mathrm{FeO}^{\mathrm{T}} / \mathrm{MgO}$ ratios (Figs. 4a-4c, Fig. 5) are high in Pikes Peak granitoids and, for many samples, significantly higher than "average" A-type granites. These ratios distinguish between the sodic and potassic series for rocks with $<\sim 70-72$ wt \% $\mathrm{SiO}_{2}$ (Fig. 4). Potassic
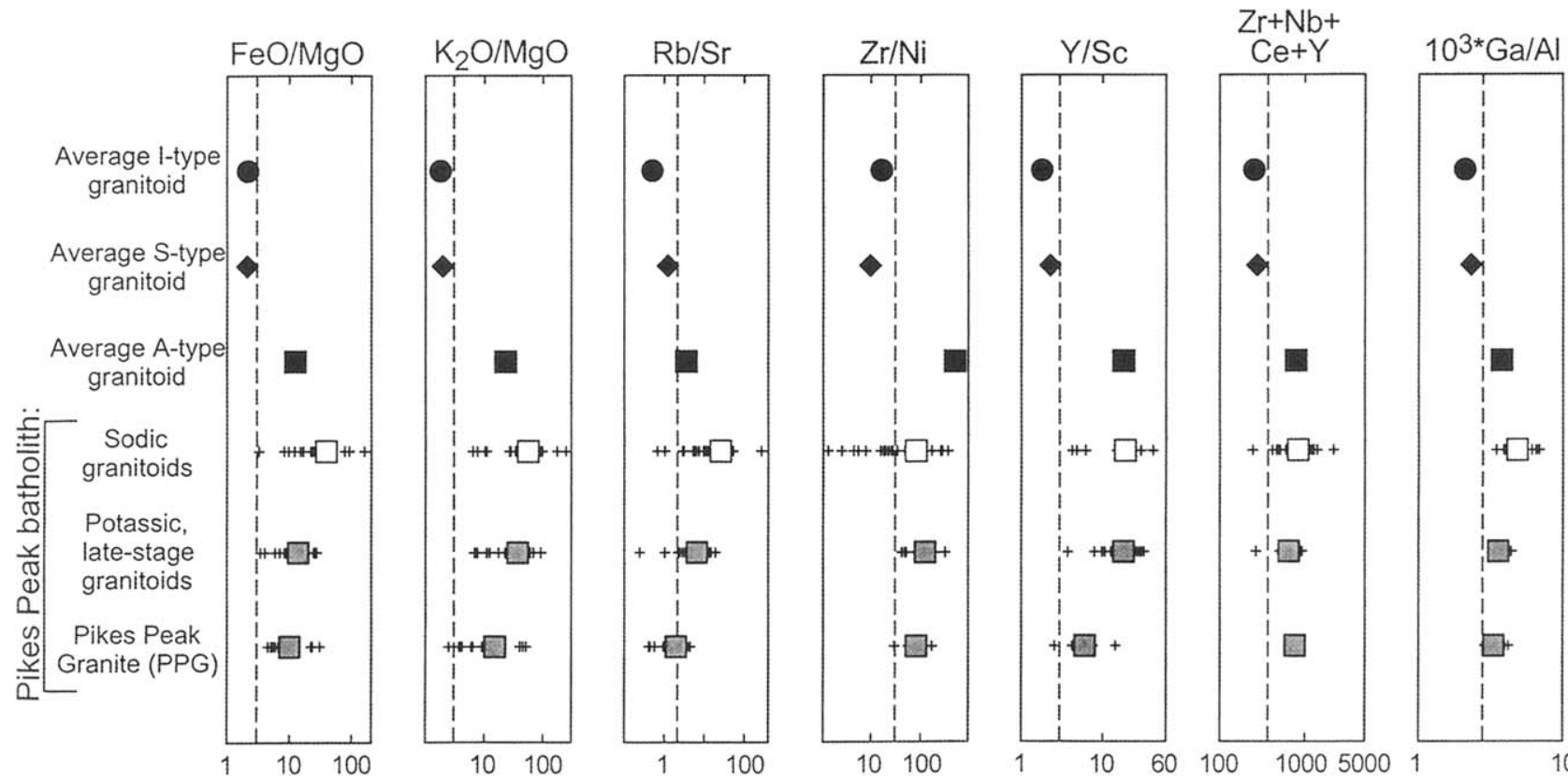

Figure 5. Major and trace element characteristics that serve to distinguish A-type granitoids from I- and S-type granitoids (data from Whalen et al., 1987 and White and Chappell, 1983). Data for Pikes Peak samples from Smith et al. (1999) shown by open and shaded squares (average values) and pluses (total range in values). Note that log scales are used. 
series granitoids have lower $\mathrm{FeO}^{\mathrm{T}} / \mathrm{MgO}$ (or higher Mg-numbers), and higher $\mathrm{CaO}$ and lower $\mathrm{Na}_{2} \mathrm{O}$ abundances compared to the sodic series. Granite with $>\sim 70$ wt $\% \mathrm{SiO}_{2}$ can be distinguished as being either sodic or potassic based on ferromagnesian silicate mineralogy (i.e., the presence or absence of fayalite and/or sodic amphiboles) and whether diabase dikes, gabbro, and/or syenite are found in association with the granite (cf. Table 2).

\section{Trace Elements}

Pikes Peak gabbros and mafic (diabase) dikes exhibit large ranges in many incompatible trace elements (e.g., Rb, Th, REE, Hf, Y). Abundances of many trace elements in Pikes Peak mafic rocks are similar to those in ocean island basalts (OIB), but OIB do not exhibit the Nb-Ta depletions that characterize Pikes Peak mafic rocks (Fig. 6). Subductionrelated basalts exhibit $\mathrm{Nb}-\mathrm{Ta}$ depletions similar to
Pikes Peak mafic rocks, but have lower abundances of most incompatible elements and higher $\mathrm{Sr}$ contents.

All Pikes Peak granitoids exhibit trace element characteristics typical of A-type granites (Fig. 5), including high abundances of incompatible elements (e.g., light REE, Nb, Y, Ga) and depletions in Sr, Eu, Sc, Ni, and Co (cf. Whalen et al., 1987). Their compositions plot in fields for A-type and "withinplate" granites on various discrimination diagrams commonly employed in the granite literature (e.g., Whalen et al., 1987; Pearce et al., 1984). Trends in some trace element abundances and ratios (e.g., $\mathrm{Rb}$ / Sr, Y/Sc, and Ba; Fig. 7) with silica allow distinction between the sodic and potassic granitoids with up to $\sim 70-72$ wt \% silica. At higher silica contents, the distinctions in trace (and major) element characteristics become blurred. Compared to coeval mafic rocks, the sodic syenites and granites exhibit

Table 2. Petrologic and geochemical features of rocks in sodic and potassic late-stage plutons.

\begin{tabular}{|c|c|c|}
\hline & Sodic & Potassic \\
\hline Rock types & $\begin{array}{c}\text { gabbro; diabase; anorthosite } \\
\text { (rare); syenite; } \\
\text { quartz syenite; granite }\end{array}$ & $\begin{array}{c}\text { syenogranite; } \\
\text { monozogranite (minor) }\end{array}$ \\
\hline Fayalite in granitoids? & Yes & No \\
\hline Sodic amphiboles in granitoids? & Yes & No \\
\hline Range in silica & $\sim 44$ to 78 wt $\%$ & $\sim 64$ to 78 \\
\hline $\begin{array}{l}{ }^{87} \mathrm{Sr} /{ }^{86} \mathrm{Sr} \text { at } 1.03 \mathrm{Ga}^{\dagger} \\
\text { Mafic } \\
\text { Intermediate } / \text { felsic }\end{array}$ & $\begin{array}{c}0.70440 \\
0.7052 \text { to } 0.7068\end{array}$ & $\begin{array}{c}\text { n.d. } \\
0.7967 \text { to } 0.7117\end{array}$ \\
\hline $\begin{array}{l}\varepsilon_{\mathrm{Nd}}(1.08 \mathrm{Ga}) \\
\quad \text { Mafic } \\
\text { Intermediate } / \text { felsic }\end{array}$ & $\begin{array}{l}+3.5 \text { to }-3.0 \\
+2.2 \text { to }-0.7\end{array}$ & $\begin{array}{c}\text { n.d. } \\
-0.2 \text { to }-2.7\end{array}$ \\
\hline $\begin{array}{l}\delta^{18} \mathrm{O} \text { (whole rock) } \\
\quad \text { Mafic } \\
\text { Intermediate/felsic }\end{array}$ & $\begin{array}{l}+6.5 \text { to }+8.1 \\
+7.2 \text { to }+8.9\end{array}$ & $\begin{array}{l}\text { n.d. } \\
+8.2 \text { to }+9.5\end{array}$ \\
\hline Other features & $\begin{array}{l}\text { Six of the sodic intrusive centers } \\
\text { appear to be aligned in a } \\
\text { NW-SE direction. }\end{array}$ & $\begin{array}{l}\text { No preferred orientation } \\
\text { of the late-stage potassic plutons } \\
\text { is evident. }\end{array}$ \\
\hline
\end{tabular}

† Barker et al. (1976) used an age of $1.03 \mathrm{Ga}$ to calculate the ${ }^{87} \mathrm{Sr} /{ }^{86} \mathrm{Sr}$ initial ratios presented here. Barker et al. (1976) did not publish ${ }^{87} \mathrm{Rb} /{ }^{86} \mathrm{Sr}$ data, thus initial ratios at $1.08 \mathrm{Ga}$ could not be recalculated. See text for further discussion.

Notes: The PPG (not included here) exhibits geochemical features that overlap with those of the potassic series.

n.d. = no data . 
enrichments in most incompatible elements (e.g., $\mathrm{Rb}, \mathrm{Th}, \mathrm{U}, \mathrm{REE}$ ), and depletions in elements that are preferentially incorporated in feldspars $(\mathrm{Ba}, \mathrm{Sr}$, $\mathrm{Eu}$ ) and ferromagnesian silicates (e.g., Sc, Co; Figs. 8 and 9). However, abundances of high field strength elements (HFSE) and light REE exhibit considerable scatter among the sodic syenites and granites, and they are often lower compared to abundances in the mafic rocks (Fig. 9).

\section{Isotopes}

Although there is overlap, slight differences in $\mathrm{Sr}, \mathrm{Nd}$, and $\mathrm{O}$ isotopic ratios exist between granitoids of the sodic and potassic series, and indicate a greater crustal component in the potassic granitoids compared to the sodic granitoids (Table 2). Unfortunately, the high $\mathrm{Rb} / \mathrm{Sr}$ ratios that characterize Pikes Peak granitoids make correction for in situ radiogenic $\mathrm{Sr}$ production and calculation of $\mathrm{Sr}$ initial ratios from whole-rock analyses imprecise. In addition, the very low Sr contents in the granitoids makes them highly sensitive to crustal contamination. Even small amounts of Sr from crustal partial melts or from hydrothermal fluids could significantly change their ${ }^{87} \mathrm{Sr} /{ }^{86} \mathrm{Sr}$ ratio (Van Breeman et al., 1975). Barker et al. (1976) provided initial

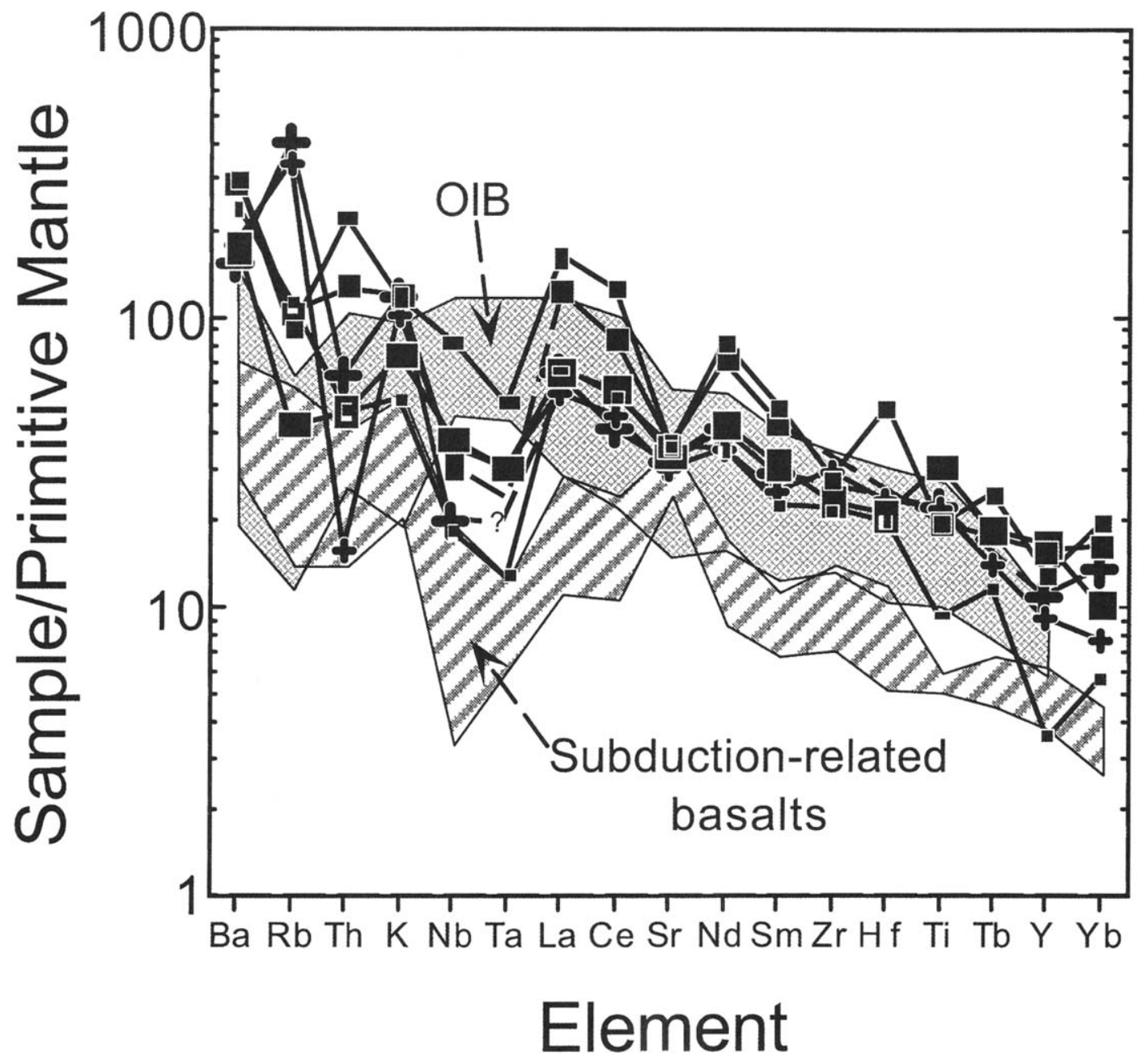

Figure 6. Primitive mantle-normalized trace element diagrams for mafic (diabase) dikes and gabbros of the Pikes Peak batholith; normalizing values from Taylor and McLennan (1985). Symbols for the mafic dikes are crosses, and symbols for the gabbros are shaded squares and rectangles. The symbols vary in size in order to help distinguish among the individual samples. The shaded field represents typical ocean island basalts (OIB; Weaver, 1991) and the ruled field represents typical subduction-related basalts (from Wilson, 1989). 


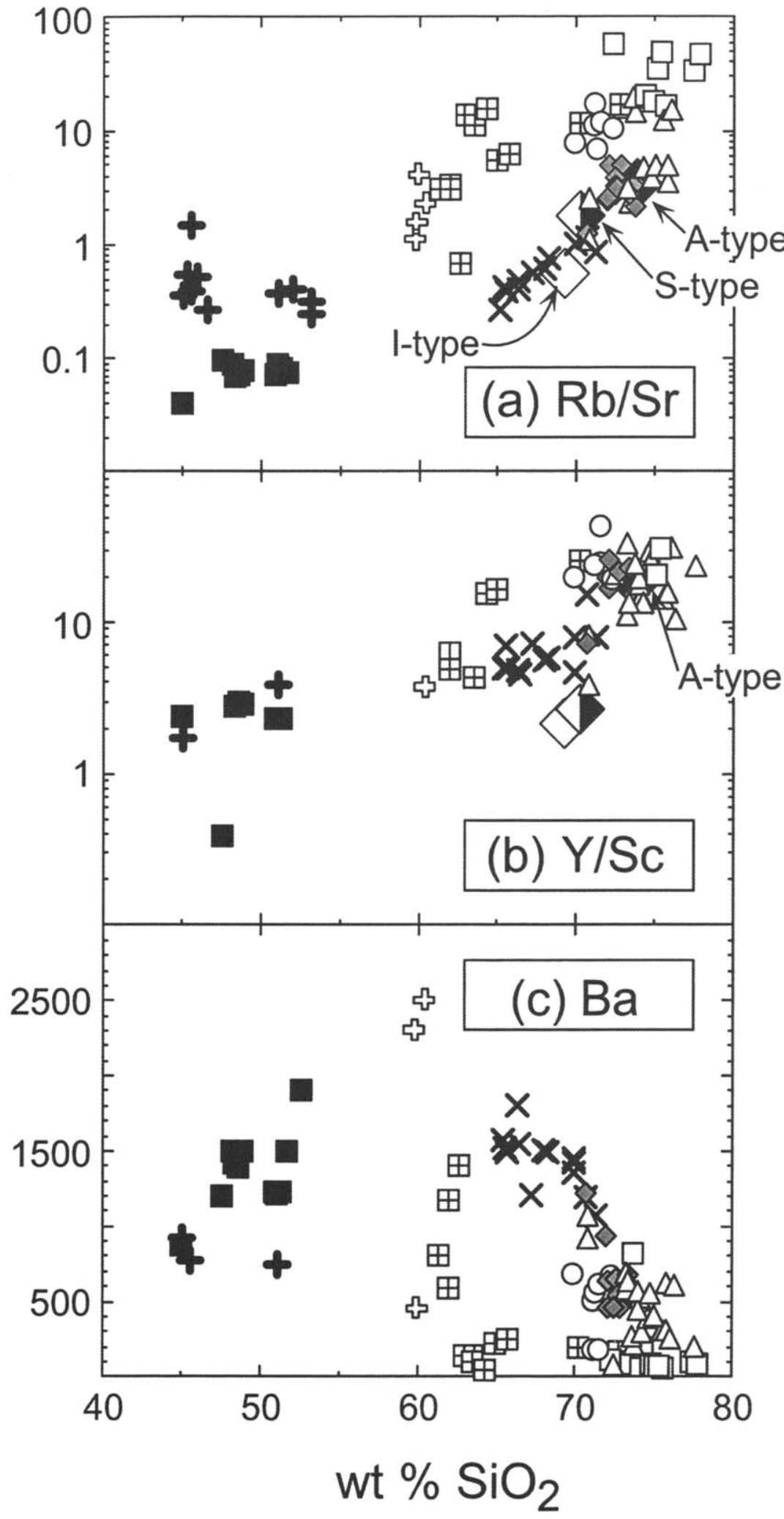

Figure 7. A, $\log \mathrm{Rb} / \mathrm{Sr} ; B, \log \mathrm{Y} / \mathrm{Sc}$; and $C, \mathrm{Ba}(\mathrm{ppm})$ versus weight \% silica in Pikes Peak rocks. Shaded diamonds represent pink syenogranites of the PPG; other symbols as in Fig. 4. Data sources include Simmons et al. (1987b) and Smith et al. (1999). Data points for average S-, I-, and A-type granites shown in panels $A$ and $B$ are from Whalen et al. (1987).
${ }^{87} \mathrm{Sr} /{ }^{86} \mathrm{Sr}$ values for a variety of rock types within the batholith for an age of $1.03 \mathrm{Ga}$, the accepted age of the batholith in the 1970s. These initial values range from 0.704-0.707 for gabbro and syenite to $0.707-0.712$ for potassic granite (Table 2). Additional $\mathrm{Rb}-$ Sr data have been obtained by Unruh (unpublished data) that exhibit similar ranges in initial ${ }^{87} \mathrm{Sr} /{ }^{86} \mathrm{Sr}$ to those obtained by Barker et al. when calculated for an age of $1.03 \mathrm{Ga}$. When an age of $\sim 1.08 \mathrm{Ga}$ is used, the calculated initial ratios of the gabbros and syenites become slightly lower (0.703-0.705), but those of the whole-rock splits from potassic granites become much lower, some unrealistically low $(<0.70$; Unruh, unpublished data). Analyses of plagioclase and other low$\mathrm{Rb} / \mathrm{Sr}$ minerals from these rocks suggest that initial ${ }^{87} \mathrm{Sr} /{ }^{86} \mathrm{Sr}$ values of 0.705-0.709 might be more appropriate for the "true" initial $\mathrm{Sr}$ ratios at the time of emplacement. However, the Rb-Sr mineral-isochron apparent ages obtained by Unruh are significantly younger $(1.02-1.05 \mathrm{Ga}$; similar to the whole-rock isochron age determined by Hedge, 1970) than the 1.08-1.09-Ga emplacement ages determined by the $\mathrm{U}-\mathrm{Pb}$ data. Consequently, the $\mathrm{Rb}-\mathrm{Sr}$ systems of many of these rocks were evidently open for a considerable amount of time after the apparent time of emplacement. Therefore, the calculation of "true" initial ${ }^{87} \mathrm{Sr} /{ }^{86} \mathrm{Sr}$ for many of these samples at the time of emplacement of the plutons is extremely difficult.

Figure 10 illustrates $\varepsilon_{\mathrm{Nd}}$ versus age for Pikes Peak rocks (Smith et al., 1999), as well as $\varepsilon_{\mathrm{Nd}}$ for wall rocks to the batholith (DePaolo, 1981). The gabbros exhibit the largest range in $\varepsilon_{\mathrm{Nd}}$ at $1.08 \mathrm{Ga}$, from +3.5 to -3.0 . Sodic syenites and granites have values of $\varepsilon_{\mathrm{Nd}}$ at 


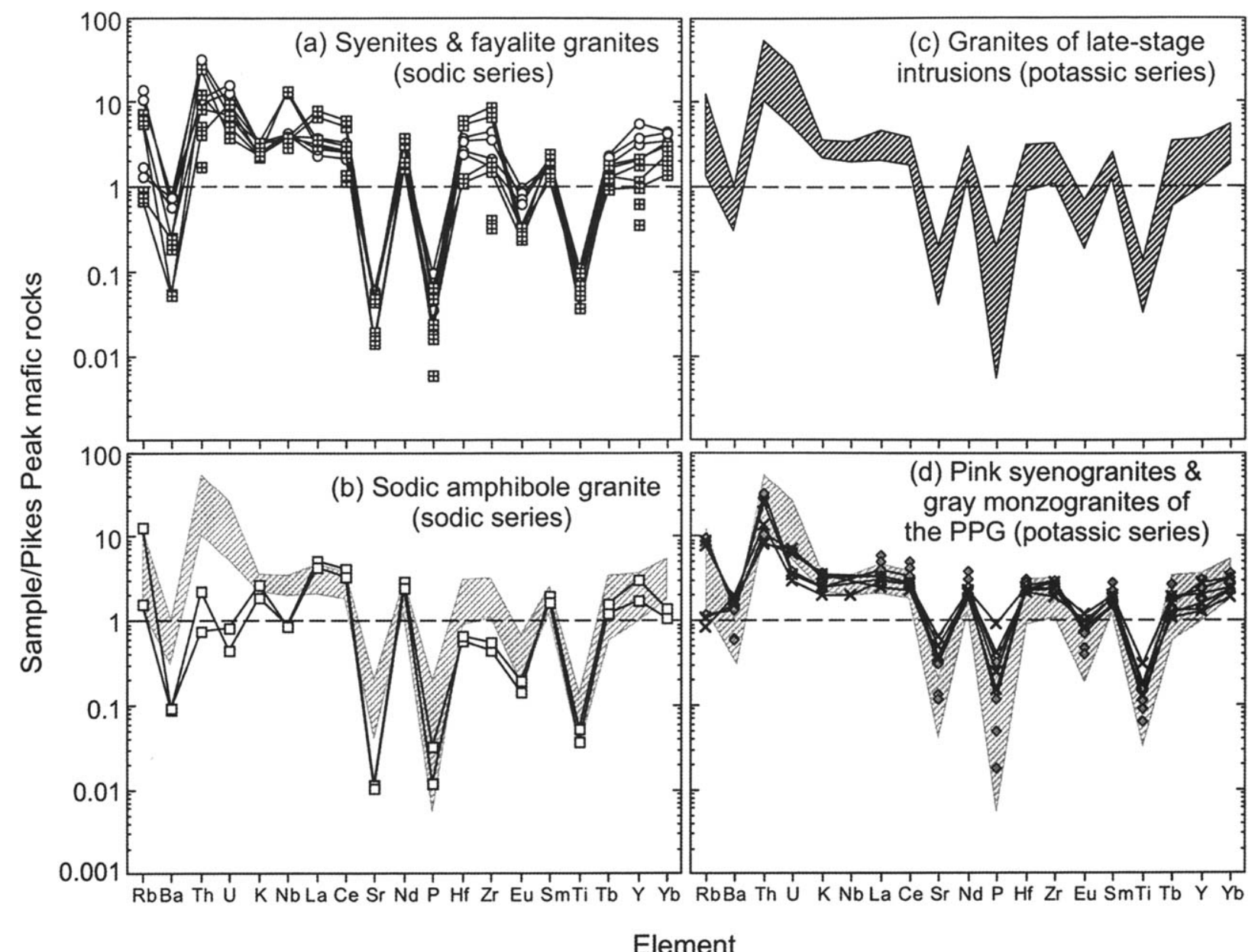

Figure 8. Representative compositions of Pikes Peak sodic rocks (panels $A$ and $B$ ) and potassic rocks (panels $C$ and D) normalized to selected Pikes Peak mafic rocks (gabbro sample CCN-19B-CD and mafic dike sample MBC-8-SG). The field for potassic granites of the late-stage intrusions (cf. panel $C$ ) is also shown in panels $B$ and $D$. Note the depletions in $\mathrm{Ba}, \mathrm{Sr}, \mathrm{P}, \mathrm{Eu}$, and $\mathrm{Ti}$, but enrichments in incompatible elements for all the granitoids, and the larger depletions in $\mathrm{Th}, \mathrm{U}, \mathrm{Hf}$, and $\mathrm{Zr}$ in the sodic amphibole granites (panel $B$ ).

$1.08 \mathrm{Ga}$ that plot between depleted mantle and Colorado crust. Values of $\varepsilon_{\mathrm{Nd}}$ for the potassic series granites generally plot within or above the range for Colorado crust at $1.08 \mathrm{Ga}$.

The ${ }^{18} \mathrm{O} /{ }^{16} \mathrm{O}$ ratios were determined in whole-rock samples of the batholith (Barker et al., 1976). The use of whole rock $\delta^{18} \mathrm{O}$ data in the evaluation of magma sources can be problematic if the rocks were susceptible to isotopic exchange due to alteration by flu- ids. Interaction with fluids at various temperatures can either lower (high temperature) or raise (low temperature) initial $\delta^{18} \mathrm{O}$ values (Javoy and Weis, 1987). Javoy and Weis (1987) found a way to get to the original composition by analyzing quartz, for which the kinetics of $\mathrm{O}$-isotope exchange are very sluggish below $450^{\circ} \mathrm{C}$. Values of $\delta^{18} \mathrm{O}$ for Pikes Peak whole rock samples exhibit internal consistency and suggest a crustal contribution in the granitoids
(Barker et al., 1976). However, isotopic analyses of quartz in these rocks should be conducted in order to evaluate the effects of isotopic exchange.

\section{PETROGENETIC MODELS}

\section{Introduction}

Barker et al. (1975, 1976) and Wobus (1976a, 1976b) suggested that the different chemical trends for the potassic and sodic series 


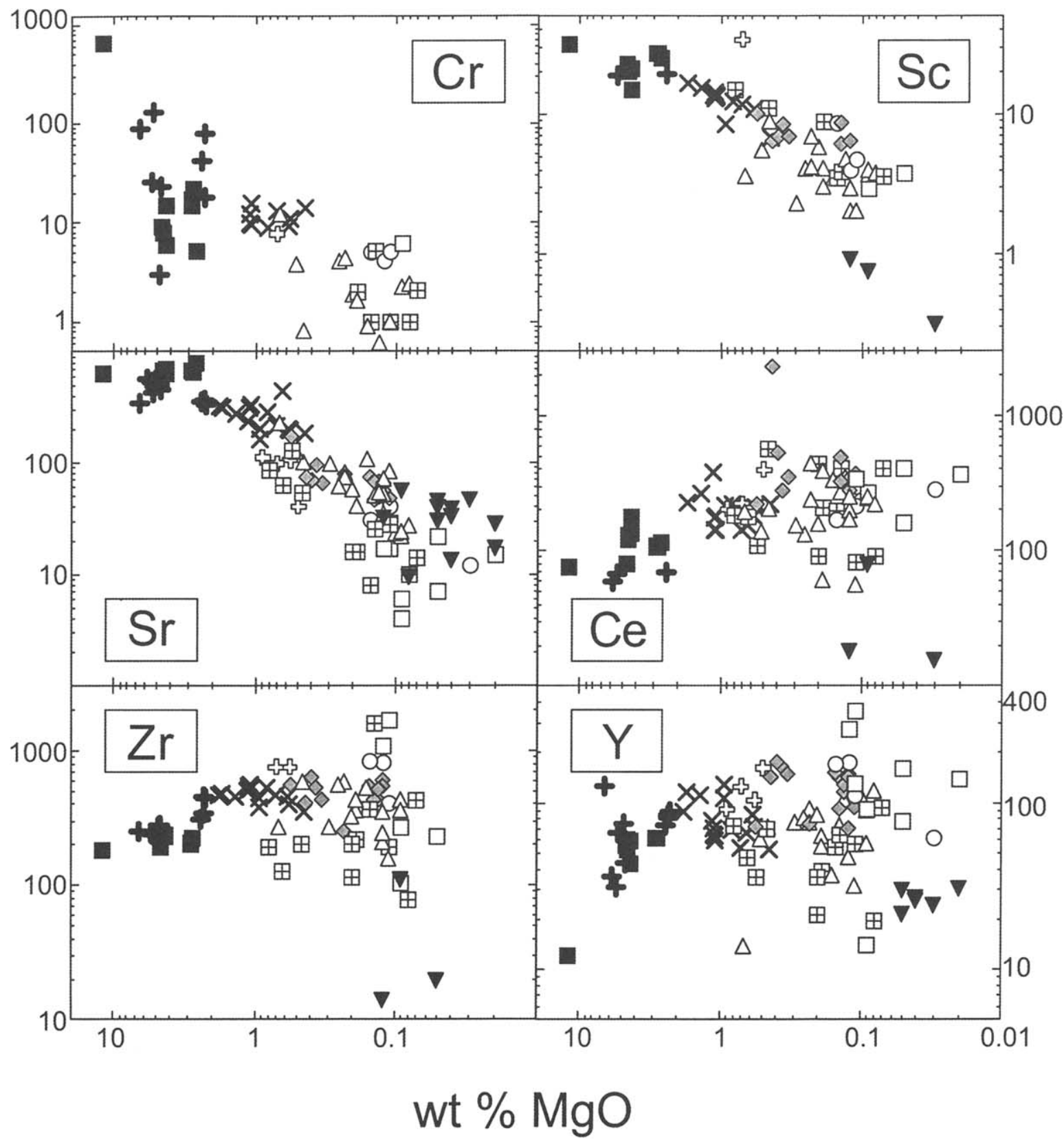

Figure 9. $\log \mathrm{Cr}, \mathrm{Sc}, \mathrm{Sr}, \mathrm{Ce}, \mathrm{Zr}$, and Y (ppm) versus weight $\% \mathrm{MgO}$ in Pikes Peak rocks. Symbols as in Figs. 4 and 7 and data sources as in Fig. 7. Also shown are pegmatite wall zone rocks (filled inverted triangles), from which $\mathrm{Sc}$, $\mathrm{Ce}, \mathrm{Zr}$, and $Y$ are thought to have been preferentially removed by residual pegmatitic fluids (Simmons et al., 1987b).

were the result of separate differentiation trends. Later studies by Smith et al. (1999) also resulted in contrasting petrogenetic models (fractionation versus crustal anatexis) for the two series.

\section{Origin of Sodic Series}

Smith et al. (1999) characterized the nature of the mantle sources that supplied mafic magmas emplaced in the late-stage sodic intrusions. Gabbros and mafic dikes have $\varepsilon_{\mathrm{Nd}}$ lower than depleted mantle at $1.08 \mathrm{Ga}$ (Fig. 10), and their primitive mantle-normalized trace element patterns (Fig. 6) exhibit overall enrichments in most elements but significant depletions in $\mathrm{Nb}, \mathrm{Ta}$, and $\mathrm{Sr}$. Smith et al. interpreted these characteristics as the result of derivation from mantle sources that were previously affected by subduction-related processes. Supra-subduction zone (SSZ) mantle sources could have developed during 


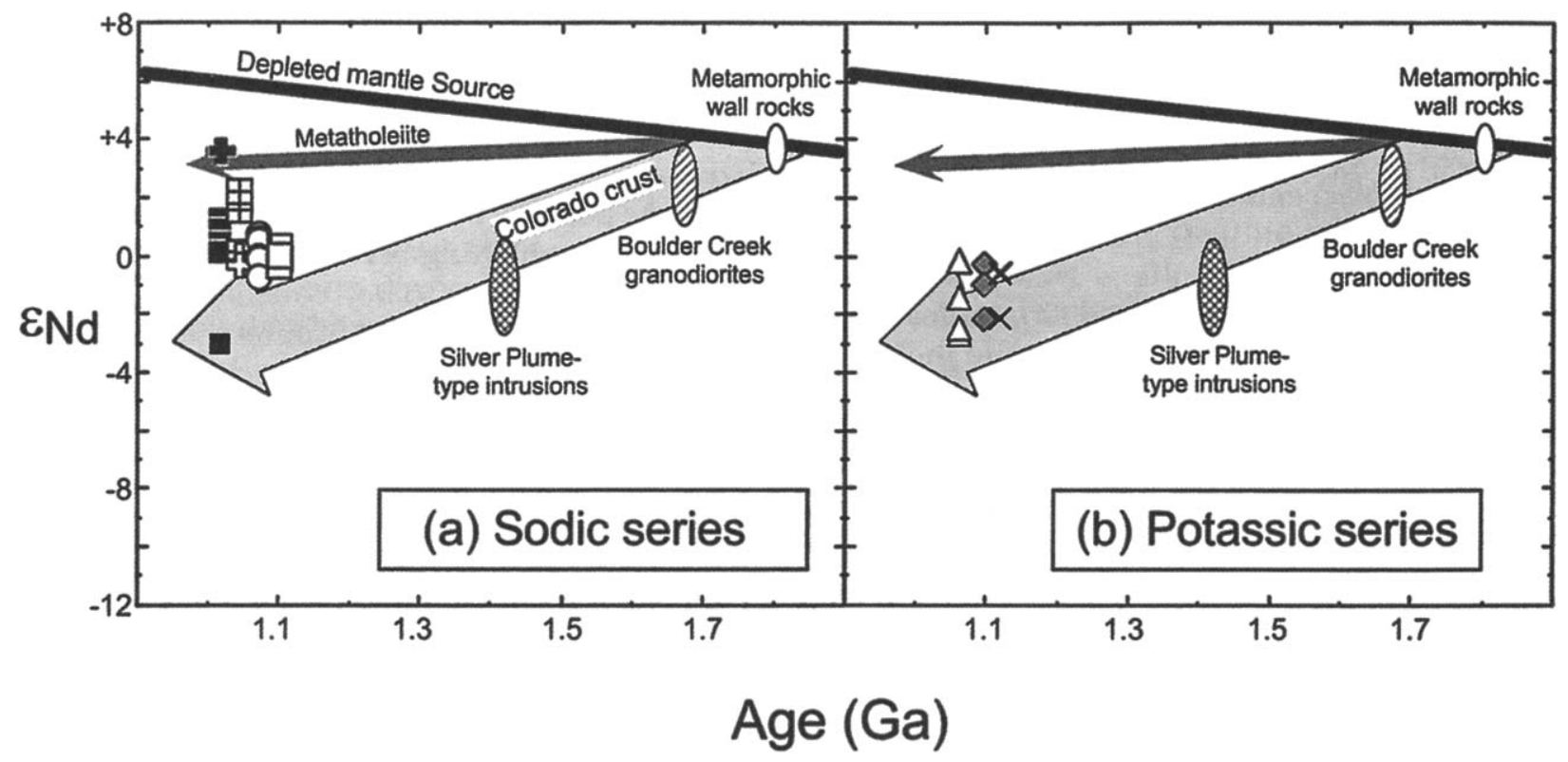

Figure 10. $\varepsilon_{\mathrm{Nd}}$ versus age relationships for $\boldsymbol{A}$, sodic series; and $\boldsymbol{B}$, potassic series rocks of the Pikes Peak batholith. The large arrow and black line show $\varepsilon_{\mathrm{Nd}}$ evolution for typical 1.8-Ga Colorado crust and depleted mantle, respectively (from DePaolo, 1981). Fields for wall rocks are from DePaolo (1981). The small arrow gives the $\varepsilon_{\mathrm{Nd}}$ evolution for typical 1.8-Ga metatholeiitic basalt (from DePaolo, 1981). Data points are separated for clarity and no age differences are implied. Symbols as in Figs. 4 and 7.

the $1.8-1.7$ Yavapai orogeny, during which the calc-alkaline Boulder Creek intrusions were emplaced. However, it is difficult to rule out contamination of mantle-derived magmas during ascent through crust (Smith et al., 1999).

Barker et al. (1975) proposed that alkalic basaltic magma trapped in the lower crust underwent simultaneous differentiation and "reaction melting" of potassium-depleted rocks of the lower crust (i.e., assimilation coupled with fractional crystallization, "AFC"; Barker, 1991) to generate syenites of the sodic series; some of these magmas underwent further fractionation to produce the sodic granites. Smith et al. (1999) also called upon basalt fractionation as a dominant process in the formation of sodic syenites and granites, but concluded that crustal assimilation played a limited role, as Barker et al. (1976) concluded for the case of the Spring Creek pluton. Poor correlation exists between $\varepsilon_{\mathrm{Nd}}$ and 1/ Nd in Pikes Peak rocks, and AFC models show that assimilation involving Boulder Creek- or Silver Plume-type intrusives cannot generate the high $\mathrm{Nd}$ concentrations observed in most sodic granitoids, even at extreme degrees of evolution, unless the rate of assimilation relative to crystallization is held to a low value.

Frost and Frost (1997) pointed out that the reduced nature of the sodic syenites and granites
(Frost et al., 1988) severely limits the potential sources, and suggested that underplated tholeiitic basalts, characterized by low $f_{\mathrm{Oz}}$, were good candidates. Barker et al.'s 1975 model also involved $\mathrm{K}_{2} \mathrm{O}$ depleted lower crustal rocks as assimilants. However, metatholeiites exposed in wall rocks of the batholith have low Nd concentrations ( 10-12 ppm; DePaolo, 1981), and lower continental crust is generally thought to have low Nd contents ( $\sim 13-19$ ppm; Taylor and McClennan, 1985; Weaver and Tarney, 1984). Minor amounts of assimilation of these materials is possible, but the high Nd contents observed in Pikes Peak granitoids seemingly require either protracted fractionation or small degrees of melting of the source.

Frost and Frost (1997) proposed that reduced anorogenic granites (including Pikes Peak granites) form either by extreme differentiation of basaltic melts or by partial melting of underplated basalts and their differentiates. However, melting experiments involving basaltic source compositions show that the melts produced do not have the high alkali and low $\mathrm{CaO}$ contents that characterize the sodic granitoids (Fig. 11). Frost and Frost (1997) did not consider basalt fractionation the dominant petrogenetic mechanism for anorogenic granites in general because of the large amount of cumulate material that must be removed, and because many 
anorogenic suites do not exhibit the continuum from voluminous gabbro to minor granite expected for a differentiation sequence. But in the case of the Pikes Peak sodic series, these problems do not pose obstacles to acceptance of fractionation models. A positive ( +35 milligal) gravity anomaly has been documented for the Pikes Peak batholith (Qureshy, 1958; cf. Hutchinson, 1960b), indicating that mafic rocks exist at depth, which could include cumulates formed during differentiation of the sodic series. Barker et al. (1976) cited the aeromagnetic results and interpretations of Zietz and Kirby (1972), which suggest that mafic and ultramafic cumulates still underlie the batholith. The sodic series comprises a small proportion $(<2 \%)$ of the exposed rocks, thus huge quantities of cumulates are not required. Furthermore, the compositional range for the sodic series is not bimodal; intermediate compositions are present as well (Fig. 4; Table 2).

Smith et al. (1999) pointed out some features of Pikes Peak sodic syenites and granites and associated mafic rocks that cause difficulties with attempts to quantify the fractionation process. In particular, some syenites of Sugarloaf (see Beane and Wobus, this issue) and sodic amphibole granites of Mount Rosa exhibit ranges in HFSE and light REE (Figs. 8 and 9) that are not easily explained by fractionation involving major phases. Accessory mineral fractionation and/or the removal of late-stage fluids (e.g., fluorine-rich volatile phases, residual pegmatitic fluids) influenced the distribution of HFSE and light REE in those rocks. Simmons et al. (1987b) presented strong evidence that $\mathrm{Th}, \mathrm{REE}, \mathrm{Zr}$, and $\mathrm{Y}$ were depleted in some Pikes Peak potassic granitoids by removal of residual pegmatitic fluids (cf. Fig. 9; see below). It is possible that similar processes affected some sodic magmas, with significant sodic pegmatite occurrences in the Mount Rosa and Sugarloaf intrusive centers.

In addition, the nature of parental mafic magmas remains uncertain because the mafic rocks sampled clearly have undergone significant fractionation themselves, and may not represent primary magmas that were parental to sodic syenites and granites (Smith et al., 1999). If SSZ (or OIBlike; cf. Fig. 6) mantle sources supplied mafic magmas that were parental to sodic syenites and granites by fractionation, it is difficult to quantify crust versus mantle contributions in the sodic granitoids. Sodic granitoids with low $\varepsilon_{\mathrm{Nd}}(T)$ could be mistaken for crust + depleted mantle mixtures, whereas they may contain little (or no) crust if parental mafic magmas had $\varepsilon_{\mathrm{Nd}}$ lower than depleted mantle at 1.08 Ga (cf. Fig. 10).

\section{Origin of Potassic Series}

Barker et al. $(1975,1976)$ hypothesized that syenitic and/or mantle-derived basaltic magmas crystallized and reacted with mid-crustal rocks to produce the potassic PPG, but acknowledged the difficulty in distinguishing between this process and partial melting of crust. They concluded that generally low $\mathrm{Sr}$ abundances and pronounced negative $\mathrm{Eu}$ anomalies in the granitoids, and progressive increases in REE abundances, initial ${ }^{87} \mathrm{Sr} /{ }^{86} \mathrm{Sr}$, and $\delta^{18} \mathrm{O}$ with increasing differentiation were supportive of an AFC model.

In a review of the origin of anorogenic granites occurring worldwide, Rogers and Satterfield (1994) included the PPG as a representative example. They called upon an important role for $\mathrm{CO}_{2}$ during either melting and/or crystallization, which influences biotite equilibria and results in negative $\mathrm{K}_{2} \mathrm{O}-\mathrm{SiO}_{2}$ relationships in anorogenic granites.

Other workers have discussed processes that may have played significant roles in the distribution of trace elements in some Pikes Peak potassic granitoids. Ludington (1981) concluded that trace element abundances in the Redskin granite arose through liquid-state fractionation (cf. Hildreth, 1979), rather than by crystal fractionation or partial melting processes. Simmons et al. (1987b) demonstrated the importance of partitioning of certain trace elements, especially REE and HFSE, into residual pegmatitic fluids, thus "stripping" these elements from the host magma (PPG).

Smith et al. (1999) hypothesized that the origin of the potassic series granites, in both the late-stage intrusions and the PPG of the main batholith, was dominated by partial melting of crustal sources. Based on comparisons with experimentally produced melts from a variety of crustal lithologies, tonalitic sources were found to be the most consistent with observed compositions of the potassic granites (Fig. 11). Mafic sources do not yield melts with the observed alkali and/or $\mathrm{CaO}$ contents of the potassic (nor the sodic) granitoids. $\mathrm{Nd}$ isotopic data are also generally consistent with crustal anatectic models for the potassic granites (Fig. 10). Some potassic granitoids, specifically the minor gray monzogranites of the PPG, are not readily interpreted as melts of tonalitic source rocks (Fig. 11) and seemingly require a mafic or juvenile (mantle derived?) component. The origin of the gray monzogranites remains unclear, but mixing between granitic melts derived from tonalitic sources and intermediate melts derived from ferrodiorite sources (Fig. 11; cf. Smith et al., 1999) is an appealing proposal. However, compositional data on par- 
tial melts from ferrodiorites are rare, and further studies are warranted in order to test this hypothesis.

Trace element characteristics of some potassic granites are consistent with moderate degrees of fractionation dominated by feldspar. Some samples have $\mathrm{Rb} / \mathrm{Sr}$ values greater than 5 (Fig. 7a), which Halliday et al. (1991) showed probably are the result of crystal fractionation rather than partial melting processes. Those samples have low $\mathrm{Ba}$ and $\mathrm{Sr}$ contents, which can be modeled as the result of $\sim 20-30$ percent crystallization and removal of a feldspar-dominated assemblage from partial melts of tonalitic source rocks (Smith et al., 1997; Smith et al., 1999). However, Smith et al. (1999) considered fractionation as a secondary, rather than the dominant, petrogenetic process in the origin of the potassic granites. But they acknowledged that it is difficult to rule out Barker et al.'s 1975 AFC model involving mafic parental magmas for the

Figure 11. Weight $\% \mathrm{~A}, \mathrm{~K}_{2} \mathrm{O} ; \mathrm{B}, \mathrm{Na}_{2} \mathrm{O}$; and $C, \mathrm{CaO}$ versus weight $\% \mathrm{SiO}_{2}$ in Pikes Peak potassic granitoids and mafic rocks (symbols as in Figs. 4 and 7, and data sources as in Fig. 4). The dashed lines encircle compositions of Pikes Peak sodic granitoids. Shaded fields include compositions of melts generated from mafic source rocks; data from Holloway and Burnham (1972), Helz (1976), Spulber and Rutherford (1983), Rushmer (1991) and Beard and Lofgren (1991). Ruled and speckled fields (see panel $A$ ) represent melts produced in experiments involving fluid-absent melting of tonalitic gneiss (ruled fields; Skjerlie and Johnston, 1993) and melts generated by partial melting of granodiorite and tonalite at 4 and 8 kbar (speckled fields; Patiño Douce, 1997). Also shown is a melt composition (cross in circle) generated from a ferrodiorite source (Scoates et al., 1996).

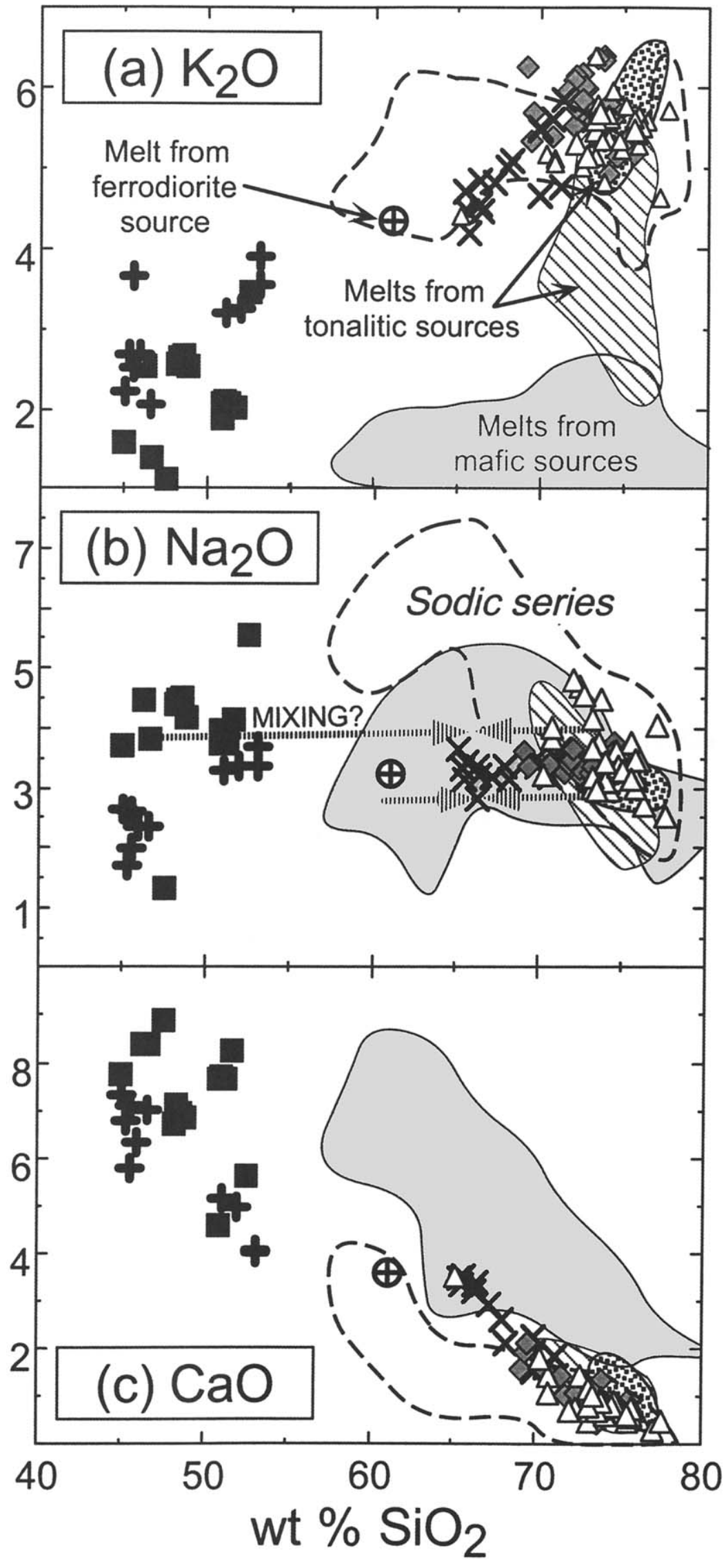


origin of the potassic granites, especially if exposed mafic rocks do not accurately represent the parental compositions. Smith's group favored a crustal anatexis model because AFC models would require huge amounts of mafic cumulates for the enormous amount of potassic granite emplaced in the batholith. Gravity and aeromagnetic data for the Pikes Peak batholith suggest the existence of significant amounts of mafic rock at depth. Not all of it may be cumulate material, but rather solidified mafic magmas that provided the heat input necessary for crustal melting. The potassic series is fairly restricted in composition. Gabbros, mafic dikes, and/or mafic enclaves are not found in association with the potassic granites, unlike the sodic series that exhibits a near continuum in composition from gabbro to granite. Crustal melting seems a more plausible way than fractionation to explain the relatively homogeneous compositions of the potassic granites, in contrast to the large compositional range exhibited by the sodic series.

\section{COMPARISON WITH TWO OTHER 1.1-Ga NORTH AMERICAN GRANITIC COMPLEXES}

Figure 1 illustrates the major tectonic and plutonic provinces that characterized the North American craton at $\sim 1.1 \mathrm{Ga}$. In addition to the Pikes Peak batholith, 1.12-1.07-Ga granites of the Llano uplift in central Texas and the 1.12-Ga Red Bluff intrusive suite of west Texas share characteristics typical of "anorogenic" granites (i.e., $\mathrm{K}$ - and Fe-rich bulk compositions, Fe-rich silicates, emplacement under low oxygen and water fugacities; Smith et al., 1997). Granitic magmas of the Llano uplift were emplaced into multiply deformed and metamorphosed crust, during or after waning stages of Grenville orogenesis (Reed and Helper, 1994). The Red Bluff granitic suite, in contrast, was emplaced into a shelf sequence north of the front of Grenville deformation, within a broad zone characterized by mild extension (cf. Smith et al., 1997 and references therein). As discussed by Smith et al. (1997), those two suites exhibit petrologic and geochemical distinctions that suggest different petrogenetic histories. The Red Bluff suite includes syenitic rocks and ferrobasaltic dikes, whereas syenitic and mafic rocks are not associated with the Llano granites. The Llano granites contain amphiboles and biotites that are more magnesian than those of the Red Bluff granitoids. Arfvedsonite occurs in Red Bluff granitoids, but alkali-rich amphiboles are lacking in the Llano granites. The Red Bluff granitoids have lower
Mg-numbers, higher $\mathrm{Na}_{2} \mathrm{O}$, and higher REE and HFSE concentrations than the Llano granites.

Figure 12 illustrates a few key diagrams that distinguish between the Pikes Peak sodic and potassic series, and which also serve to distinguish between the Red Bluff and Llano suites. The Red Bluff suite is similar to the sodic series of the Pikes Peak batholith (cf. Table 2), and it was also interpreted as having a direct derivation from mantle sources by extensive fractionation of basaltic magmas with minor crustal assimilation (Shannon et al., 1997). In contrast, the Llano granites share characteristics with the Pikes Peak potassic series (Fig. 12; Table 2), and they were also interpreted to represent anatectic melts derived from crustal sources (Smith et al., 1997).

Ranges in $\varepsilon_{\mathrm{Nd}}(\mathrm{T})$ for the Red Bluff suite $(+3.8$ to +2.5 ; Norman et al., 1987; Patchett and Ruiz, 1989) overlap with that for the Llano granites $(+4.3$ to +2.6; Patchett and Ruiz, 1989; Smith et al., 1997). In contrast, the range in $\varepsilon_{\mathrm{Nd}}(T)$ for the Llano granites is distinct from the range exhibited by the Pikes Peak potassic granites ( -0.2 to -2.7$)$. Although both suites are interpreted to represent tonalitic crustal melts, the sources apparently had different isotopic characteristics. The Llano granites were interpreted by Smith et al. (1997) as partial melts from slightly older crustal sources in which isotopic signatures did not have sufficient time to evolve to values distinct from depleted mantle. They were emplaced at the last stages of orogenesis, and perhaps tonalitic crust that developed during a previous subduction event (e.g., Mosher, 1998) served as sources for those magmas. In contrast, Pikes Peak potassic magmas were emplaced hundreds of millions of years following the 1.8-1.7-Ga Yavapai orogeny. Tonalitic crust developed during the Yavapai event had considerable time to evolve to $\varepsilon_{\mathrm{Nd}}(T)$ isotopic compositions lower than the Llano crustal sources.

Similarly, the Red Bluff granitoids $\left(\varepsilon_{\mathrm{Nd}}(\mathrm{T})=\right.$ +3.8 to +2.5$)$ and the Pikes Peak sodic granitoids $\left(\varepsilon_{\mathrm{Nd}}(\mathrm{T})=+2.2\right.$ to -0.7$)$ are thought to have a common origin by fractionation from mantle-derived magmas, but their $\varepsilon_{\mathrm{Nd}}(\mathrm{T})$ ranges indicate isotopically distinct mantle sources. Mantle sources for Pikes Peak mafic magmas appear to have been affected by subduction-related processes, as were mantle sources for Red Bluff mafic magmas (Barnes et al., this issue). However, the Pikes Peak mantle sources exhibited a wider $\varepsilon_{\mathrm{Nd}}(\mathrm{T})$ range that includes lower values $(+3.5$ to -3.0$)$ compared to Red Bluff mantle sources $(+3.5$ to +2.7 ; Patchett and Ruiz, 1989). 


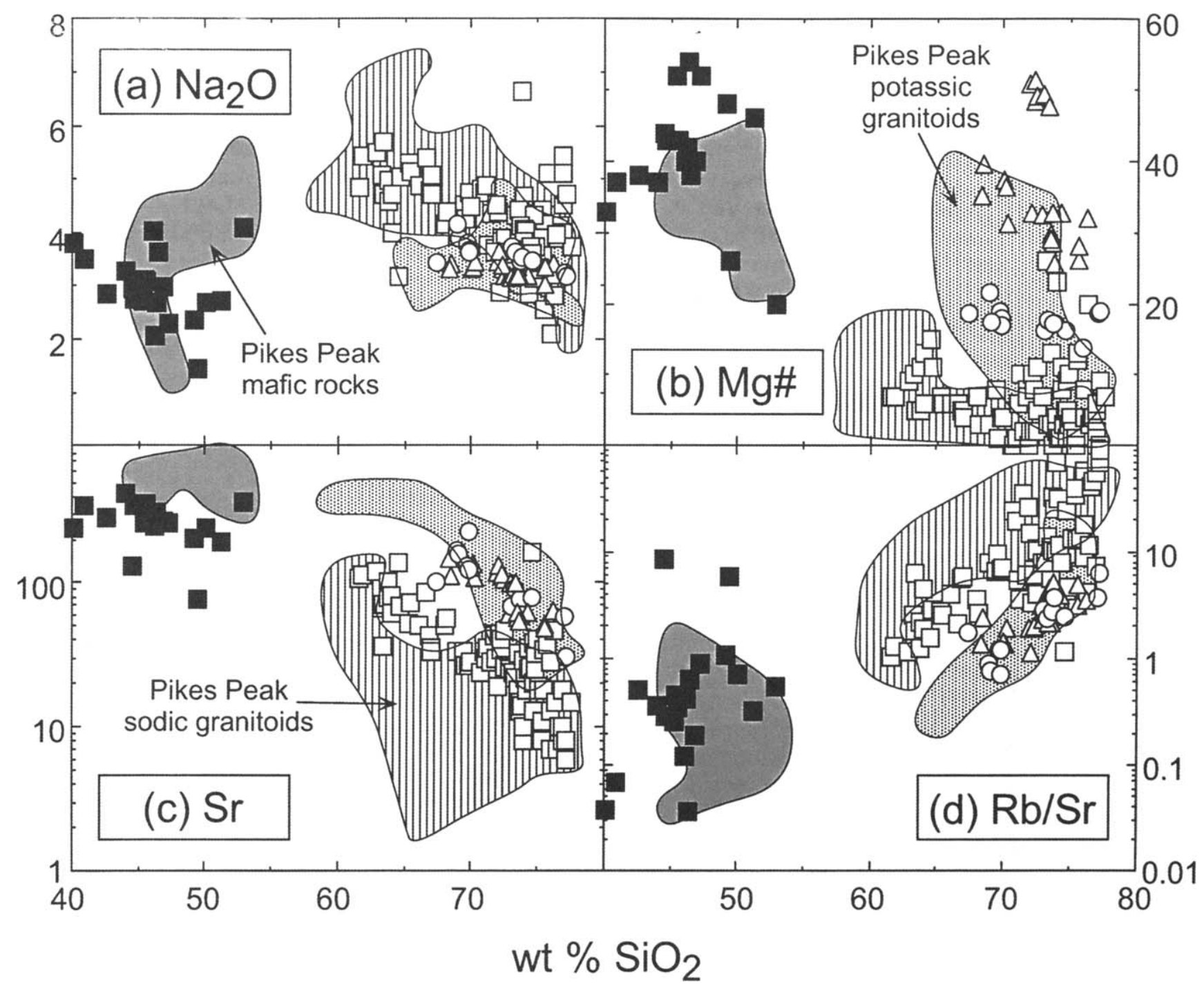

Figure 12. A, Weight \% $\mathrm{Na}_{2} \mathrm{O} ; \boldsymbol{B}, \mathrm{Mg}$-number; $\boldsymbol{C}, \log \mathrm{Sr}(\mathrm{ppm})$; and $\mathrm{D}, \log \mathrm{Rb} / \mathrm{Sr}$ versus weight \% silica for Pikes Peak rocks (represented by fields), mafic dikes (filled squares) and granitoids (open squares) of the Red Bluff suite, and granites from the Enchanted Rock batholith (open triangles) and Marble Falls intrusive center (open circles) of the Llano uplift. Data for the Red Bluff suite are from Shannon et al. (1997) and Barnes et al. (this volume). Data for the Enchanted Rock batholith are from Smith et al. (1997). Data for the Marble Falls intrusive center are from Gallegos and Smith (1996) and R. Smith (unpublished data).

\section{TECTONIC SETTING}

The tectonic setting of the Pikes Peak batholith is not well understood. Two possibilities are rifting (or extension) and a "hot spot" (or mantle plume). Barker et al. (1975) stated that a setting of incipient rifting is a likely possibility for the Pikes Peak batholith, and it is commonly thought that most Atype granites are emplaced in crust undergoing extension (e.g., Turner et al., 1992). Adams and Keller (1994) suggested that areas of $\sim 1.2-1.0-\mathrm{Ga}$ igneous activity in Texas and New Mexico (e.g, the Pecos mafic intrusive complex; Keller et al., 1989; the Red Bluff granitic suite and associated ferrobasaltic dikes, Shannon et al., 1997; cf. Fig. 1) were related to the $\sim 1.1-G a$ Midcontinent Rift (MCR). They pointed out that the scale and complexity of features associated with the MesozoicCenozoic African rift are comparable to that exhibited by areas of $\sim 1.1$ igneous activity thought to be related to the MCR. Adams and Keller included the Pikes Peak batholith on their maps, but did not directly state that it was related to MCR extension. However, the Pikes Peak batholith occurs at a distance from the MCR that is comparable to distances between off-axis features and the main axis of the 
African rift (cf. Fig. 8 in Adams and Keller, 1994). Mafic dikes in the southwestern U.S., 1.1 Ga in age, (cf. Fig. 1) have been interpreted to indicate that the area experienced extension during this time (Hammond, 1986). Those dikes are approximately as far from areas affected by extension in west Texas as the Pikes Peak batholith is from the MCR's extension into Kansas. Perhaps the 1.1-Ga North American tectonic "picture" was similar to that for the western U.S. during Cenozoic time. It could have included broad as well as linear regions affected by extension, which were distributed over a large part of the continent.

Other A-type granitic suites have been suggested as being the result of mantle plume activity. For example, the Mesozoic plutons of the White Mountain magma series in New England have been related to a "hot spot" or mantle plume (Morgan, 1981; Crough, 1981). However, McHone and Butler (1984) noted that there is no significant progression of ages among the White Mountain plutons, and they suggested that this north-south elongate province may have formed along an ancient transform or rift fault in the New England basement crust. Bédard (1985) hypothesized a setting of rifting, decompression melting, and a southeast-propagating tensional event for the White Mountain magma series. It is likewise difficult to resolve the plume versus rift origin for the Pikes Peak batholith until more details are known about its total size and distribution (cf. Tweto, 1980b) and the timing of magma emplacement.

\section{CONCLUSIONS}

Many studies of the mineralogy, petrology, geochemistry, and geochronology of Pikes Peak intrusive rocks have resulted in models for the origin and evolution of magmas emplaced in the batholith. Most workers interpret the sodic syenites and granites as fractionation products of basaltic magmas, and recent studies present evidence for minimal crustal involvement in those magmas. Potassic granites, which comprise more than 98 percent of present exposures of the batholith, were first interpreted (Barker et al., 1975, 1976) as the result of basalt fractionation coupled with assimilation of crust, but we interpret them to represent crustal melts. Details of the emplacement history of sodic and potassic magmas within the late-stage centers are not well constrained, but existing geochronologic data and field relations suggest that the sodic magmas were among the last to be emplaced in the batholith.
The following working model for the Pikes Peak batholith is offered. At $\sim 1.1 \mathrm{Ga}$, extension caused thinning of the lithosphere and triggered magma production in the mantle. Mantle-derived basaltic magmas were trapped and cooled in the lower crust, providing heat that caused anatexis of tonalitic crust. The solidified mafic magmas contributed to the gravity and aeromagnetic anomalies presently associated with the batholith. Crustal partial melts underwent low to moderate degrees of fractionation dominated by feldspar, and huge volumes of potassic granite (the Pikes Peak Granite) were emplaced at epizonal levels. Three large intrusive centers developed, fed by magmatic plumbing systems that transported magma along NW-SE directions. Mafic magmas, which were derived from supra-subduction zone mantle sources presumably affected by the 1.8-1.7-Ga Yapavai event, experienced variable degrees of crystal fractionation. Results of this process included iron-rich alkaline mafic magmas, and more extreme fractionation produced sodic syenites and granites. The sodic intrusive centers are preferentially aligned in a NW-SE direction, perhaps related to fractures or weaknesses caused by crustal extension.

\section{ACKNOWLEDGMENTS}

DRS, JBN, and RAW gratefully acknowledge the William M. Keck Foundation for its generous support of the Keck Geology Consortium, which sponsored the faculty-student research project that generated much of the data presented here. We especially thank the following students who worked on Pikes Peak rocks for their energy, productivity, and insights: Rachel Beane, Lynn Chastain, Chase Davis, Jill Douglass, Emily Giambalvo, Sami Goldman, Britta Gustavson, Gregory Kay, Ben Saltoun, Jennifer Stewart, and Marnie Sturm. We are also very grateful to the following individuals for their interest in this project and useful discussions on the origin of the Pikes Peak batholith: Lawford Anderson, Calvin Barnes, Lori BettisonVarga, Shelby Boardman, Peter Crowley, Sam Kozak, Hanna Nekvasil, Robert Schuster, and Steve Weaver. Fred Barker, Cal Barnes, Larry Snee, and Leonid Neymark are thanked for their careful and constructive reviews.

\section{REFERENCES CITED}

Adams, D. C., and Keller, G. R., 1994, Possible extension of the Midcontinent Rift in west Texas and eastern New Mexico: Canadian Journal of Earth Sciences, v. 31, p. 709-720. 
Adams, J. W., and Young, E. J., 1961, Accessory bastnaesite in the Pikes Peak granite, Colorado: U.S. Geological Survey Professional Paper 424-C, p. C292-C294.

Aldrich, L. T., Wetherill, G. W., and Davis, G. L., 1957, Occurrence of 1350 million-year old granitic rocks in western United States: Geological Society of America Bulletin, v. 68, p. 655-656.

Anderson, J. L., 1983, Proterozoic anorogenic granite plutonism of North America: Geological Society of America Memoir 161, p. 133-154.

Anderson, J. L., and Morrison, J., 1992, The role of anorogenic granites in the Proterozoic crustal development of North America, in Condie, K., ed., Proterozoic crustal evolution: Amsterdam, Elsevier, p. 263-299.

Barker, F., 1991, A-type granites revisited: Assessment of a residual source model: Comment: Geology, v. 19, p. 1151.

Barker, F., Wones, D. R., Sharp W. N., and Desborough, G. A., 1975, The Pikes Peak Batholith, Colorado Front Range, and a model for the origin of the gabbro-anorthosite-syenitepotassic granite suite: Precambrian Research, v. 2, p. $97-$ 160.

Barker, F., Hedge, C., Millard, H., and O'Neil, J., 1976, Pikes Peak Batholith: Geochemistry of some minor elements and isotopes, and implications for magma genesis, in Epis, R. C. and Weimer, R. J., eds., Studies in Colorado field geology: Golden, Colorado School of Mines Professional Contributions, v. 8, p. 44-56.

Barnes, C. G., Shannon, W. M., and Kargi, H., 1999, Diverse Middle Proterozoic basaltic magmatism in west Texas: Rocky Mountain Geology, this issue.

Beane, R. J., 1993, Field relations, petrology and geochemistry of the Sugarloaf complex, Pikes Peak Batholith, Colorado [Bachelor's Honors Thesis]: Williamstown, Massachusetts, Williams College, $56 \mathrm{p}$.

Beane, R. J., and Wobus, R. A., 1993, Field relations, petrography and geochemistry of the Sugarloaf intrusive center, Pikes Peak batholith, Colorado [abs.]: Eos (American Geophysical Union Transactions), v. 74, p. 634.

1999, Petrogenesis of the Sugarloaf syenite, Pikes Peak batholith, Colorado: Rocky Mountain Geology, this issue.

Beard, J. S., and Lofgren, G. E., 1991, Dehydration melting and water-saturated melting of basaltic and andesitic greenstones and amphibolites at 1, 3, and $6.9 \mathrm{~kb}$ : Journal of Petrology, v. 32, p. 365-104.

Bédard, J. H., 1985, The opening of the Atlantic, the Mesozoic New England province, and mechanisms of continental breakup: Tectonophysics, v. 113, p. 209-232.

Bickford, M. E., 1988, The formation of continental crust: Part 1. A review of some principles; Part 2. An application to the Proterozoic evolution of southern North America: Geological Society of America Bulletin, v. 100, p. 1375-1391.

Brewster, R. H., 1986, The distribution and chemistry of rareearth minerals in the South Platte pegmatite district, Colorado, and their genetic implications [Master's thesis]: New Orleans, University of New Orleans, 139 p.

Bryant, B., Barker, F., Wobus, R. A., and Hutchinson, R. M., 1976, Road log, Pikes Peak batholith field trip, in Epis, R. C., and Weimer, R J., eds., Studies in Colorado field geology: Golden, Colorado School of Mines Professional Contributions, v. 8, p. 17-31.

Bryant, B., McGrew, L. S., and Wobus, R. A., 1981, Geologic map of the Denver $1^{\circ}$ by $2^{\circ}$ quadrangle, north-central Colorado:
U.S. Geological Survey Miscellaneous Investigations Map I1163, scale 1:250 000, 2 sheets.

Chappell, B. W., and White, A. J. R., 1974, Two contrasting granite types: Pacific Geology, v. 8, p. 173-174.

Chastain, L. M., and Noblett, J. B., 1994, Magma mingling in the anorogenic Proterozoic West Creek pluton, Pikes Peak batholith, Colorado: Geological Society of America Abstracts with Programs, v. 26, no. 6, p. A8.

Collins, W. J., Beams, S. D., White, A. J. R, and Chappell, B. W., 1982, Nature and origin of A-type granites with particular reference to southeastern Australia: Contributions to Mineralogy and Petrology, v. 80, p. 189-200.

Cross, C. W., 1894, Description of the Pikes Peak sheet (Colorado): U.S. Geological Survey, Geological Atlas, Folio 7.

Cross, C. W., and Hillebrand, W. F., 1882, Notes on some interesting minerals occurring near Pikes Peak, Colorado: American Journal of Science, v. 24, p. 281-286.

Crough, S. T., 1981, Mesozoic hotspot epeirogeny in eastern North America: Geology, v. 9, p. 2-6.

DePaolo, D. J., 1981, Neodymium isotopes in the Colorado Front Range and crust-mantle evolution in the Proterozoic: Nature, v. 291, p. 193-196.

Douglass, J., and Smith, D. R., 1993, Neodymium isotopic constraints on the origin of alkaline plutons of the Pikes Peak batholith: Geological Society of America Abstracts with Programs, v. 25, no. 6, p. A261-A262.

Epis, R. C., Scott, G. R., and Taylor, R. B., 1973, Petrologic, tectonic, and geomorphic history of central Colorado, in Rocky Mountain Section Guidebook for Field Trips, Field Trip No. 8: Boulder, Geological Society of America, p. 25-26.

Finlay, G. I., 1916, Description of the Colorado Springs quadrangle (Colorado): U.S. Geological Survey, Geological Atlas, Folio 203.

Foord, E. E., Sharp, W. N., and Adams, J. W., 1984, Zinc- and Ygroup-bearing senaite from St. Peters Dome and new data on senaite from Dattas, Minas Gerais, Brazil: Mineralogical Magazine, v. 48, p. 97-106.

Frost, B. R, Lindsley, D. H, and Andersen, D. J., 1988, Fe-Ti oxide-silicate equilibria: Assemblages with fayalitic olivine: American Mineralogist, v. 73, p. 727-740.

Frost, C. D., and Frost, R. B., 1997, Reduced rapakivi-type granites: The tholeiite connection: Geology, v. 25, p. 647-650.

Gable, D. J., 1980, The Boulder Creek batholith, Front Range, Colorado: U.S. Geological Survey Professional Paper 1101 $88 \mathrm{p}$.

Gallegos, M. A., and Smith, R. K., 1996, Petrology and geochemistry of the $1.07 \mathrm{Ga}$ Granite Mountain exfoliation dome, eastern Llano uplift, central Texas: South Texas Geological Society Bulletin, v. 37, issue 3, p. 11-21.

Giambalvo, E., 1993, Amphibole chemistry in alkaline igneous rocks of the Pikes Peak batholith, Colorado [Bachelor's Honors Thesis]: Amherst, Massachusetts, Amherst College, 99 p.

Giffin, C. E., and Kulp, J. L., 1960, Potassium-argon ages in the Precambrian basement of Colorado: Geological Society of America Bulletin, v. 71, p. 219-222.

Goldman, S. R., Kay, G., Noblett, J. B., Saltoun, B., and BettisonVarga, L., 1994, Petrology of the Proterozoic Mount Rosa intrusive complex, Pikes Peak batholith: Geological Society of America Abstracts with Programs, v. 26, no. 6, p. A14. 
Gross, E. B., and Heinrich, E. W., 1965, Petrology and mineralogy of the Mount Rosa area, El Paso and Teller counties, Colorado. I. The granites: American Mineralogist, v. 50, p. 1273-1295.

1966, Petrology and mineralogy of the Mount Rosa area, El Paso and Teller counties, Colorado. III. Lamprophyres and mineral deposits: American Mineralogist, v. 51, p. 14331442.

Halliday, A. N., Davidson, J. P., Hildreth, W., and Holden, P., 1991, Modeling the petrogenesis of high $\mathrm{Rb} / \mathrm{Sr}$ silicic magmas: Chemical Geology, v. 92, p. 107-114.

Hammond, J. G., 1986, Geochemistry and petrogenesis of Proterozoic diabase in the southern Death Valley region of California: Contributions to Mineralogy and Petrology, v. 93, p. 312-321.

Hanley, J. B., Heinrich, E. W., and Page, L. R., 1950, Pegmatite investigations in Colorado, Wyoming and Utah, 1942-1944: U.S. Geological Survey Professional Paper 227, 125 p.

Harrison, T. M. and Watson, E. B., 1984, The behavior of apatite during crustal anatexis: Equilibrium and kinetic considerations: Geochimica et Cosmochimica Acta, v. 48, p. 14641477.

Hawley, C. C., 1969, Geology and beryllium deposits of the Lake George (or Badger Flats) beryllium area, Park and Jefferson counties, Colorado: U.S. Geological Survey Professional Paper 608-A, $44 \mathrm{p}$.

Hawley, C. C., Huffman, C., Jr., Hamilton, J. C., and Rader, L. F., 1966, Geologic and geochemical features of the Redskin Granite and associated rocks, Lake George beryllium area, Colorado: U.S. Geological Survey Professional Paper 500-C, p. $\mathrm{C} 138-\mathrm{C} 147$.

Hawley, C. C., and Wobus, R. A., 1977, General geology and petrology of the Precambrian crystalline rocks, Park and Jefferson counties, Colorado: U.S. Geological Survey Professional Paper 608-B, 77 p.

Haynes, C. V., Jr., 1965, Genesis of the White Cloud and related pegmatites, South Platte area, Jefferson County, Colorado: Geological Society of America Bulletin, v. 76, p. 441-462.

Hedge, C. E., 1970, Whole-rock Rb-Sr age of the Pikes Peak batholith, Colorado: U.S. Geological Survey Professional Paper 700-B, p. B86-B89.

Heinrich, E. W., 1958, Rare-earth pegmatites of the South PlatteLake George area, Douglas, Teller, and Park counties, Colorado [abs.]: Geological Society of America Bulletin, v. 69, p. 1579-1580.

Helz, R. T., 1976, Phase relations of basalts in their melting ranges at $\mathrm{P}_{\mathrm{H} 2 \mathrm{O}}=5 \mathrm{~kb}$. Part II. Melt compositions: Journal of Petrology, v. 17, p. 139-193.

Hildreth, E. W., 1979, The Bishop Tuff: Evidence for the origin of zoned magma chambers: Geological Society of America Special Paper 180, p. 43-72.

Hoffman, P. F., 1988, United plates of America, the birth of a craton: Early Proterozoic assembly and growth of Laurentia: Annual Reviews of Earth and Planetary Science, v. 16, p. 543-603.

Holloway, J. R., and Burnham, C. W., 1972, Melting relations of basalt with equilibrium water pressure less than total pressure: Journal of Petrology, v. 13, p. 1-29.

Hutchinson, R. M., 1959a, $A^{40} / K^{40}$ age determinations of the north end of Pikes Peak batholith, Jefferson, Douglas, and Park counties, Colorado [abs.]: Geological Society of America Bulletin, v. 70, p. 1779.
$1959 \mathrm{~b}, \mathrm{~A}^{40} / \mathrm{K}^{40}$ age determinations of rock associated with north end of Pikes Peak batholith, Jefferson, Douglas, and Park counties, Colorado [abs.]: Geological Society of America Bulletin, v. 70, p. 1622.

1960a, Road log, Denver to Bailey, in Tectonics and economic geology of central Colorado, Field trip A-3, in Weimer, R. J., and Haun, J. D., eds., Guide to the Geology of Colorado: Denver, Rocky Mountain Association of Geologists, p. 132-144.

$1960 \mathrm{~b}$, Structure and petrology of north end of Pikes Peak batholith, Colorado, in Weimer, R. J., and Haun, J. D., eds., Guide to the Geology of Colorado: Denver, Rocky Mountain Association of Geologists, p. 170-180.

1976, Granite-tectonics of Pikes Peak batholith, in Epis, R. C., and Weimer, R. J., eds., Studies in Colorado field geology: Colorado School of Mines Professional Contributions, v. 8, p. 32-43.

Hutchinson, R. M., and Hedge, C. E., 1967, Precambrian basement rocks of the central Colorado Front Range and its 700million year history: Geological Society of America, Rocky Mountain Section Guidebook, 51 p.

Javoy, M., and Weis, D., 1987, Oxygen isotopic composition of alkaline anorogenic granites as a clue to their origin: The problem of crustal oxygen: Earth and Planetary Science Letters, v. 84, p. 415-422.

Karlstrom, K. E., and Bowring, S. A., 1987, Early Proterozoic assembly of tectonostratigraphic terranes in southwestern North America: Journal of Geology, v. 96, p. 561-576.

Keller, G. R., Hills, J. M., Baker, M. R., and Wallin, E. T., 1989, The Nellie intrusion: A basic stratiform intrusion in the Central basin platform in west Texas: Geology, v. 17, p. 10491052.

Krogh, T. E., 1973, A low contamination method for hydrothermal decomposition of zircon and extraction of $\mathrm{U}$ and $\mathrm{Pb}$ for isotopic age determinations: Geochimica et Cosmochimica Acta, v. 37, p. 488-494.

Lee, M. T., 1986, Major and minor element geochemistry of the South Platte granite-pegmatite system, Jefferson County, Colorado [Master's thesis]: New Orleans, University of New Orleans, $122 \mathrm{p}$.

Loiselle, M. C., and Wones, D. R., 1979, Characteristics and origin of anorogenic granites: Geological Society of America Abstracts with Programs, v. 11, no. 7, p. A468.

Ludington, S., 1981, The Redskin Granite: Evidence for thermogravitational diffusion in a Precambrian granite batholith: Journal of Geophysical Research, v. 86, p. 10,42310,430 .

Ludwig, K. R., 1988, PBDAT for MS-DOS, a computer program for IBM-PC compatibles for processing raw $\mathrm{Pb}-\mathrm{U}-\mathrm{Th}$ isotope data, version 1.24: U.S. Geological Survey Open-File Report 88-542, 32 p.

1991, ISOPLOT for MS-DOS, a plotting and regression program for radiogenic-isotope data, for IBM-PC compatible computers, version 2.75: U.S. Geological Survey Open-File Report 91-445, 45 p.

Marshall, B. D., and DePaolo, D. J., 1982, Precise age determinations and petrogenetic studies using the K-Ca method: Geochimica et Cosmochimica Acta, v. 46, p. 2537-2545.

Mathews, E. B., 1895, The granites of Pikes Peak, Colorado: Geological Society of America Bulletin, v. 6, p. 471-473. 1900, The granitic rocks of the Pike's Peak Quadrangle, Colorado: Journal of Geology, v. 8, p. 214-240. 
McHone, J. G., and Butler, J. R., 1984, Mesozoic igneous provinces of New England and the opening of the North Atlantic Ocean: Geological Society of America Bulletin, v. 95, p. 757-765.

Modreski, P. J., Fitzpatrick, J., Foord, E. E., and Kohnen, T. M., eds., 1986, Colorado pegmatites; abstracts, short papers, and field guides from the Colorado Pegmatite Symposium: Denver, Friends of Mineralogy, Mineralogical Society of America, $160 \mathrm{p}$.

Morgan, W. J., 1981, Hotspot tracks and the opening of the Atlantic and Indian Oceans, in Emiliani, C., ed., The oceanic lithosphere: The sea, Volume 7: New York, John Wiley and Sons, p. 443-487.

Mosher, S., 1998, Tectonic evolution of the southern Laurentian Grenville orogenic belt: Geological Society of America Bulletin, v. 110, p. 1357-1375.

Muntyan, B., and Muntyan, J. R., 1985, Minerals of the Pikes Peak granite: Mineralogical Record, v. 16, p. 217-230.

Norman, D. I., Condie, K. C., Smith, R. W., and Thomann, W. F., 1987, Geochemical and $\mathrm{Sr}$ and $\mathrm{Nd}$ isotopic constraints on the origin of late Proterozoic volcanics and associated tinbearing granites from the Franklin Mountains, west Texas: Canadian Journal of Earth Sciences, v. 24, p. 830-839.

Parrish, R. R., Roddick, J. C., Loveridge, W. D., and Sullivan, R. D., 1987, Uranium-lead analytical techniques at the geochronology laboratory, Geological Survey of Canada, in Radiogenic age and isotopic studies, Report 1: Geological Survey of Canada Paper 87-2, p. 3-7.

Patchett, P. J., and Ruiz, J., 1989, Nd isotopes and the origin of Grenville-age rocks in Texas: Implications for Proterozoic evolution of the United States mid-continent region: Journal of Geology, v. 97, p. 685-695.

Patiño Douce, A. E., 1997, Generation of metaluminous A-type granites by low-pressure melting of calc-alkaline granitoids: Geology, v. 25, p. 743-746.

Pauly, H., 1954, Weberite from Pikes Peak, Colorado: American Mineralogist, v. 39, p. 669-674.

Pearce, J. A., Harris, N. B. W., and Tindle, A. G., 1984, Trace element discrimination diagrams for the tectonic interpretation of granitic rocks: Journal of Petrology, v. 25, p. 956-983.

Peterman, Z. E., and Hedge, C. E., 1968, Chronology of Precambrian events in the Front Range, Colorado: Canadian Journal of Earth Sciences, v. 5, p. 749-756.

Peterson, W. L., 1964, Geology of the Platte Canyon quadrangle, Colorado: U.S. Geological Survey Bulletin 1181-C, 23 p.

Pitcher, W. S., 1983, Granite: Typology, geological environment and melting relationships, in Atherton, M. P., and Gribble, C. D., eds., Migmatites, melting and metamorphism: Nantwich, United Kingdom, Shiva, p. 277-285.

Qureshy, M. N., 1958, Gravity anomalies and a suggested genesis for Pikes Peak batholith, Front Range Colorado [abs.]: Geological Society of America Bulletin, v. 69, p. 1740.

Reed, J. C., Jr., Bickford, M. E., Premo, W. R., Aleinikoff, J. N., and Pallister, J. S., 1987, Evolution of the Early Proterozoic Colorado province: Constraints from U-Pb geochronology: Geology, v. 15, p. 861-865.

Reed, R. M., and Helper, M. A., 1994, Evidence for solid-state deformation of $\sim 1.1 \mathrm{Ga}$ "anorogenic" granites in the Llano Uplift, Texas: Geological Society of America Abstracts with Programs, v. 26, no. 1, p. A25.
Rogers, J. J. W., and Satterfield, M. E., 1994, Fluids of anorogenic granites: A preliminary assessment: Mineralogy and Petrology, v. 50, p. 157-171.

Rushmer, T., 1991, Partial melting of two amphibolites: Contrasting experimental results under fluid-absent conditions: Contributions to Mineralogy and Petrology, v. 107, p. 4159.

Sage, R. P., 1966, Geology and mineralogy of the Cripple Creek syenite stock, Teller County, Colorado [Master's thesis]: Golden, Colorado School of Mines, 236 p.

Saltoun, B., 1993, A petrologic and geochemical analysis of the fayalite-bearing granitoids, Mount Rosa intrusive center, Colorado [Bachelor's thesis]: Wooster, Ohio, College of Wooster, $50 \mathrm{p}$.

Schärer, U., and Allègre, C. J., 1982, Uranium-lead system in fragments of a single zircon grain: Nature, v. 295, p. 585-587.

Scoates, J. S., Frost, C. D., Mitchell, J. N., Lindsley, D. H., and Frost, R. B., 1996, Residual-liquid origin for a monzonitic intrusion in a mid-Proterozoic anorthosite complex: The Sybille intrusion, Laramie anorthosite complex, Wyoming: Geological Society of America Bulletin, v. 108, p. 1357-1371.

Scott, G. R., Taylor, R. B., Epis, R. C., and Wobus, R. A., 1978 Geologic map of the Pueblo $1^{\circ}$ by $2^{\circ}$ quadrangle, south-central Colorado: U.S. Geological Survey Miscellaneous Investigations Map I-1022, scale 1:250 000, 2 sheets.

Shannon, W. M., Barnes, C. G., and Bickford, M. E., 1997, Grenville magmatism in west Texas: Petrology and geochemistry of the Red Bluff granitic suite: Journal of Petrology, v. 38, p. 1279-1305.

Simmons, W. B., 1977, Structural and mineralogical relationships of pegmatites in the South Platte District, Colorado, in Proceedings, Friends of Mineralogy Symposium No. 3: Friends of Mineralogy, Mineralogical Society of America, p. 1.

Simmons, W. B., and Hanson, S. L., 1991, A comparison of HREE mineralization in the Trout Creek Pass and South Platte pegmatite districts, Colorado: Geological Society of America Abstracts with Programs, v. 23, no. 4, p. A94.

Simmons, W. B., and Heinrich, E. W., 1975, A summary of the petrogenesis of the granite-pegmatite system in the northern end of the Pikes Peak batholith: Fortschritte der Mineralogie, v. 52, p. 251-264.

1980, Rare-earth pegmatites of the South Platte District, Colorado: Resource Series no. 11, Denver, Colorado Geological Survey, $131 \mathrm{p}$

Simmons, W. B., Lee, M. T., and Brewster, R. H., 1987a, Rare-earthelement zonation in the Pikes Peak batholith: Geological Society of America Abstracts with Programs, v. 19, no. 5, p. A334.

1987b, Geochemistry and evolution of the South Platte granite-pegmatite system, Jefferson County, Colorado: Geochimica et Cosmochimica Acta, v. 51, p. 455-471.

Simmons, W. B., Lee, M. T., Brewster, R. H., and Wayne, D. M., 1986, Chemical fractionation and evolution of the South Platte pegmatite suite, Jefferson County, Colorado, in Papers and Proceedings of the $14^{\text {th }}$ General Meeting, International Mineralogical Association, p. 232.

Skjerlie, K. P., and Johnston, A. D., 1993, Fluid absent melting behavior of an F-rich tonalitic gneiss at mid-crustal pressures: Implications for the generation of anorogenic granites: Journal of Petrology, v. 34, p. 785-815. 
Smith, D. R., Barnes, C., Shannon, W., Roback, R., and James, E. 1997, Petrogenesis of Mid-Proterozoic granitic magmas: Examples from central and west Texas: Precambrian Research, v. 85, p. 53-79.

Smith, D. R., and eleven others, 1999, Petrology and geochemistry of late-stage intrusions of the A-type, Mid-Proterozoic Pikes Peak batholith, central Colorado (USA): Implications for petrogenetic models: Precambrian Research, v. 98, p. 271-305.

Spulber, S. D., and Rutherford, M. J., 1983, The origin of rhyolite and plagiogranite in oceanic crust: An experimental study: Journal of Petrology, v. 24, p. 1-25.

Stacey, J. S., and Kramers, J. D., 1975, Approximation of terrestrial lead isotope evolution by a two-stage model: Earth and Planetary Science Letters, v. 26, p. 207-221.

Steiger, R. H., and Jäger, E., 1977, Subcommission on Geochronology: Convention on the use of decay constants in geoand cosmochronology: Earth and Planetary Science Letters, v. 36, p. 359-362.

Stewart, D. D., 1964, Geology and petrology of the Lake George syenite stock, Park and Teller counties, Colorado [Master's thesis]: Golden, Colorado School of Mines, 115 p.

Stewart, J. L., 1994, Geochemistry and petrogenesis of the syenoand monzo-granites from the Pikes Peak area, southern Front Range, Colorado: Geological Society of America Abstracts with Programs, v. 26, no. 5, p. A63.

Sturm, M., Smith, D. R., Beane, R., Wobus, R. A., Gustavson, B. Kay, G., Saltoun, B., and Stewart, J., 1993, Geochemistry of late stage alkaline intrusions of the Pikes Peak batholith, Colorado: Geological Society of America Abstracts with Programs, v. 25, no. 6, p. A261.

Taylor, S. R., and McLennan, S. M., 1985, The continental crust: Its composition and evolution: Oxford, Blackwell, $312 \mathrm{p}$.

Tilton, G. R., Aldrich, L. T., Davis, G. L., and Wetherill, G. W., 1957, Isotopic ages of zircon from granites and pegmatites: American Geophysical Union Transactions, v. 38, p. 360 371.

Turner, S. P., Foden, J. D., and Morrison, R. S., 1992, Derivation of some A-type magmas by fractionation of basaltic magma: An example from the Padthaway Ridge, South Australia: Lithos, v. 28, p. 151-179.

Tweto, O., 1980a, Rock units of the Precambrian basement of Colorado: U.S. Geological Survey Professional Paper 1321A, $54 \mathrm{p}$.

1980b, Precambrian geology of Colorado, in Kent, H. C., and Porter, K., eds., Colorado geology: Denver, Rocky Mountain Association of Geologists, p. 37-46.

Van Breeman, O., Hutchinson, J., and Bowden, P., 1975, Age and origin of the Nigerian Mesozoic granites: $\mathrm{A} \mathrm{Rb}-\mathrm{Sr}$ isotopic study: Contributions to Mineralogy and Petrology, v. 50, p. 157-172.

Voynick, S., 1994, Pikes Peak pegmatites; "America's Mountain" offers excellent rockhounding: Rock and Gem, v. 24, p. 48$50,82-84$.

Watson, E. B., and Harrison, T. M., 1983, Zircon saturation revisited: Temperature and composition effects in a variety of crustal magma types: Earth and Planetary Science Letters, v. 64, p. $295-304$.
Wayne, D. M., 1986, Electron microprobe analysis of rare-earthelement-bearing phases from the White Cloud pegmatite, South Platte district, Jefferson County, Colorado [Master's thesis]: New Orleans, University of New Orleans, 122 p.

Weaver, B. L., 1991, The origin of ocean island basalt end-member compositions: Trace element and isotopic constraints: Earth and Planetary Science Letters, v. 104, p. 381-397.

Weaver, B., and Tarney, J., 1984, Empirical approach to estimating the composition of the continental crust: Nature, v. 310, p. 575-577.

Whalen, J. B., Currie, K. L., and Chappell, B. W., 1987, A-type granites: Geochemical characteristics, discrimination and petrogenesis: Contributions to Mineralogy and Petrology, v. 95, p. 407-419.

White, A. J. R., and Chappell, B. W., 1983, Granitoid types and their distribution in the Lachlan Fold Belt, southeastern Australia: Geological Society of America Memoir 159, p. 2134.

Wilson, M., 1989, Igneous petrogenesis: London, Unwin Hyman Ltd., 466 p.

Wobus, R. A., 1976a, New data on potassic and sodic plutons of the Pikes Peak batholith, central Colorado, in Epis, R. C., and Weimer, R. J., eds., Studies in Colorado field geology: Golden, Colorado School of Mines Professional Contributions, v. 8, p. 57-67.

$1976 \mathrm{~b}$, Petrogenesis of small plutons of the Pikes Peak batholith, Colorado: Geological Society of America Abstracts with Programs, v. 8, no. 6, p. A1174-A1175.

Wobus, R A., and Anderson, R. S., 1978, Petrology of the Precambrian intrusive center at Lake George, southern Front Range, Colorado: U.S. Geological Survey Journal of Research, v. 6, p. 81-94.

Wobus, R. A., and Hutchinson, R. M., 1988, Proterozoic plutons and pegmatites of the Pikes Peak region, Colorado, in Geological Society of America Centennial Meeting Field Trip Guidebook: Denver, Colorado, Geological Society of America, p. 35-42.

Wones, D. R., 1989, Significance of the assemblage titanite + magnetite + quartz in granitic rocks: American Mineralogist, v. 74, p. $744-749$.

Woodard, H. H., 1993, Sixth Keck Research Symposium in Geology (Abstracts volume): Wooster, Ohio, College of Wooster, Keck Geology Consortium, 300 p.

Zietz, I., and Kirby, J. R., 1972, Aeromagnetic map of Colorado: U.S. Geological Survey Geophysical Investigations Map GP0836,1 sheet.

Manuscript Submitted August 22, 1998

Revised Manuscript Submitted February 2, 1999

Manuscript ACCEPTed February 15, 1999 